\title{
Eğitim ve Bilim Dergisinde Yayınlanan Araştırmaların Eğilimleri: İçerik Analizi
}

\author{
Ziya SELÇUK ${ }^{1}$ \\ TEDMEM \\ Mehmet KANDEMİR ${ }^{3}$ \\ Kırıkkale Üniversitesi
}

\author{
Mehmet PALANCI ${ }^{2}$ \\ Karadeniz Teknik Üniversitesi \\ Hakan DÜNDAR ${ }^{4}$ \\ Kırıkkale Üniversitesi
}

$\ddot{O} z$

Bu çalışmanın amacı TED Eğitim ve Bilim dergisinde yayınlanan makalelerin içerik analizini yapmak, bu yolla dergide yayınlanan makalelerin eğilimlerini belirlemektir. Çalışmada amaçlı örnekleme yöntemi ile toplam 492 makale seçilerek analiz edilmiştir. Makalelerin seçiminde derginin SSCI tarafından dizinlendiği sayının yayınlandığı yıl olan 2007 yılı ile 2013 yılları arasındaki sayılarda yayınlanmış makaleler olmasına dikkat edilmiştir. Bu kapsamda tespit edilen makalelerin analizi için "Yayın Sınıflama Formu" kullanılmıştır. Makaleler içerik analizi yapılarak, makalenin kimliği hakkında tanımlayıcı bilgi, disiplin alanı, makalenin konusu, yöntemi, veri toplama araçları, örneklemi, veri analiz yöntemleri, tartışma ve öneriler boyutlarını kapsayacak şekilde incelenmiştir. Elde edilen veriler, yüzde ve frekansa dayalı bir şekilde yorumlanmış, tablo ve grafiklerle de verilerin gösterimine yer verilmiştir. Elde edilen verilere dayalı olarak en fazla yayının Hacettepe, Ankara ve Gazi üniversitesi gibi büyük ve daha gelişmiş üniversitelerde görev yapan bilim insanları tarafından yapıldığ 1 tespit edilmiştir. Yine en fazla yayının, eğitim programları ve öğretimi, eğitim yönetimi, matematik eğitimi ve fen bilimleri eğitimi alanlarında olduğu tespit edilmiştir. Nicel ve betimsel taramaya dayalı araştırmaların en fazla yayın olarak tespit edildiği çalışmada daha çok tutum, algı ve kişilik testlerinin veri toplama aracı olarak kullanıldığı tespit edilmiştir. Örneklem düzeyi olarak lisans düzeyinde ve 301-1000 kişilik bir örneklem aralığında çalışmaların yoğunlaşttğı görülmüştür. Verilerin analizinde ise daha çok betimsel analizlerin yapıldığı, anova ve t-testi analizlerinin çalışmalarda yoğun bir şekilde kullanıldığı tespit edilmiştir. Mevcut analizlerden yola çıkılarak yayın geçmişi, profili ve eğilimleri izlenerek TED Eğitim ve Bilim Dergisinin yayın yönelimi ve bilimsel çalışmalara katkı sağlama çerçevesi geliştirilmeye çalışılacaktır.

Anahtar Kelimeler: Eğitim ve Bilim, araştırma, içerik analizi, yöntem

\section{Giriş}

Eğitim araştırmaları, eğitim alanına özgü araştırma süreçlerini kapsayan ve çeşitli yöntemlerle elde edilen verilerin sistematik olarak kaydedilmesi, analiz edilmesi ve yayımlanması süreci olarak bilinmektedir (Mortimore, 2000). Eğitim sistemine kuramsal dayanaklar oluşturma, politikalar kazandırma ve uygulamalar geliştirmede önemli bir rolü bulunan eğitimle ilgili bu araştırmalar son yıllarda akademik dünyada büyük bir artış göstermektedir. Bu eğitim araştırmalarından bazıları eğitim reformlarına temel oluştururken, bazıları ilgili literatürü gözden geçirme yoluyla önceki araştırma sonuçlarının güvenirliğini test etmekte bazıları ise elde edilen bulgularla yeni araştırmalara ışık tutmaktadır. Eğitim alanında yapılan bu çalışmalar eğitim sisteminin kalite ve işlevselliğini artırarak eğitim alanına ve araştırmacılara önemli katkılar sağladığı söylenebilmektedir (Karadağ,

\footnotetext{
${ }^{1}$ Prof. Dr., Ziya Selçuk, TEDMEM, ziyaselcuk1@yahoo.com

${ }^{2}$ Yrd. Doç. Dr., Mehmet Palancı, Karedeniz Teknik Üniversitesi, Eğitim Fakültesi, Özel Eğitim, mpalanci@gmail.com

${ }^{3}$ Yrd., Doç. Dr., Mehmet Kandemir, Kırıkkale Üniversitesi, Eğitim Fakültesi, İlköğretim,

mkandemir61@gmail.com

${ }^{4}$ Doç. Dr., Hakan Dündar, Kırıkkale Üniversitesi, Eğitim Fakültesi, İlköğretim, hdundar06@gmail.com
} 
2009; Göktaş ve diğ, 2012). Bu bağlamda önemli çalışmaları bulunan Mortimore (2000) eğitim araştırmalarının dört işlevi olduğunu ifade etmektedir. Eğitim araştırmalarının birinci işlevi, öğrenme süreçlerinde kullanmak üzere eğitimle ilgili olay ve süreçleri kavramsallaştırmak, gözlemlemek ve sistematik oluşturmaktır. İkinci işlevi yapılan gözlemleri açıklamak için kendi koşulları, bağlamları, sonuç ve içerikleri içinde bunları analiz etmektir. Üçüncü işlevi ise incelenen belirli bir konu hakkında bütün verileri yayınlamaktır. Ve eğitim bilimleri alanına katkı sağlayacak mevcut teori üzerine veya mevcut eğitim teorisinin kendisi ya da kendi sağlayacağı gelişmekte olan başka teoriler için bakış açısı kazandırmaktır. Dördüncü işlevi ise eğitim araştırmacılarının en temel amacı olarak eğitimin daha da iyileştirilmesi için çalışmalar yapmaktır.

İlgili literatürde belirlenen işlev ve görevleri yerine getirmesi için, eğitim araştırmalarının belirli aralıklarla incelenip düzenlenmesi gerekmekte ve alandaki eğilimlerin belirlenmesi, bu alanda çalışma yapan ve yapmak isteyen pek çok bilim insanına yol gösterici olmaktadır (Cohen, Manion ve Morrison, 2007). Günümüzde eğitim bilimleri alanında hemen her konu ile ilgili birbirinden bağımsız çok sayıda çalışma yapılmaktadır. Yapılan çalışmaların alana ve araştırmacılara yapacağı katkı son derece önemli bir nokta iken bu çalışmaları tasnif etme, eğilimleri ve araştırmaların sonuçlarına dayalı değerlendirmeler yapma da bir o kadar önemlidir. Bazen alanda yapılan çalışma sayısının fazlalığı bazı sorunları da beraberinde getirmektedir. Bir konudaki çalışmaların sonuçları birbirini desteklediği gibi birbiri ile çelişkili sonuçlar da ortaya çıkarabilmektedir. Herhangi bir konuda araştırma yapanlar o konuyla ilgili araştırmaların hepsine ulaşmakta zorlanmakta veya onlara ulaşmak için çok zaman harcamaktadırlar (Göktaş ve diğ, 2012). Bu noktada belli bir alanda yapılan çalışmalar ile ilgili olarak yapılan içerik ve meta analizi sonuçları araştırmacılara önemli kolaylıklar sağlamaktadır. Bu tür içerik ve meta analizi çalışmaları son yıllarda pek çok araştırmacının ilgisini çekmiştir. Eğitim bilimleri alanında yapılan bazı içerik ve meta analizi gibi çalışmalarda (Kablan, Topan ve Erkan, 2013; Göktaş ve diğ., 2012; Kılıç-Çakmak ve diğ., 2013; Tomakin ve Yeşilyurt, 2013; Chang, Chang ve Tseng, 2010; Gökçek ve diğ., 2013) eğitim alanında son yıllardaki eğilimler belirlenerek yeni çalı̧̧malar için önemli vurgular yapılmaktadır. Bu yöntemle yapılan araştırmaların bir kısmı bilim alanlarıyla, bir kısmı araştırma yöntemleriyle, bir kısmı da eğitim araştırmalarıyla ilişkili olduğu görülmektedir. Bu araştırmalar bazıları şu şekilde özetlenmiştir: Çalık, Ünal, Coştu ve Karataş (2008) fen eğitimindeki alanında yapılmış tezleri inceleyerek Türkiye'deki fen eğilimini anlamaya amaçlamıştır. Bunun için, 444 yüksek lisans ve doktora tezini bazı değişkenler açısından incelemişlerdir. Araştırma sonucunda, Türkiye'de fen eğitimleri tezlerinde araştırma yöntemi olarak deneysel yöntem ve araştırma grubu olarak ilköğretim öğrencileri olduğu bulunmuştur. Çiltaş, Güler ve Sözbilir (2012) tarafından matematik eğitimi alanında yayınlanan makaleler içerik analizi yöntemiyle incelenmiştir. Bu amaçla, 1987-2009 yılları arasında ulaşılabilen kaynaklardan, 27'si ulusal, 5'i Web of Science SSCI indeksinde bulunan uluslararası toplam 32 farklı dergide matematik eğitimi alanında yayınlanan toplam 359 araştırma incelenmiştir. Araştırma sonucunda, matematik eğitimi araştırmanlarında 2002 yılından itibaren büyük bir artışın olduğu, nicel araştırmaların daha çok tercih edildiği, araştırma konusu olarak öğrenme çalışmalarının ön planda olduğu, çalışmalarda tek veri toplama aracının daha çok kullanıldığı ve veri analiz yöntemi olarak yüzde ve frekans tablolarının kullanımının ön plana çıktığı belirlenmiştir. Göktaş ve arkadaşları (2012) tarafından, SSCI ve ULAKBIMM veri tabanları tarafından dizinlenen Türkiye'deki eğitim dergilerinde 2005-2009 yıllarında yayımlanan eğitim araştırmalarının türleri, yöntemleri, konu alanları, araştırmalarda kullanılan veri toplama araçları, veri analiz yöntemleri ve örneklem özellikleri açılarından eğilimlerinin hangi yönde olduğunu tespit etmeyi amaçlayan bir çalışma yapılmıştır. Araştırmada amaçlı örnekleme yöntemi ile seçilen 2115 makale Ĕgitim Bilimleri Yayın Sınıflama Formu (EBYSF) kullanılarak içerik analizine tabi tutulmuştur. Araştırma bulgularına göre makale türü açısından betimsel çalışmaların sıklıkla tercih edildiği; eğitim teknolojileri, fen bilimleri eğitimi, PDR ve matematik eğitiminin en çok yayın yapılan konu alanları olduğu tespit edilmiştir. Çalışmalarda en çok nicel araştırma yöntemleri kullanılırken, veri toplama aracı olarak anket ve ilgi, tutum, yetenek, kişilik testlerinin sıklıkla kullanılan araçlar olduğu; veri analiz yöntemleri arasında da betimsel veri analizinin çok kullanıldığı belirlenmiştir. Örneklem grubu olarak lisans düzeyindeki öğrencilerin ve öğretmenlerin, örneklem büyüklüğü olarak 31-100 ile 101- 
300 kişi arasında değişen grupların; örnekleme tekniği olarak da kolay ulaşılabilir örnekleme tekniğinin çok kullanıldığı belirlenmiştir. Gülbahar ve Alper (2009) tarafından yapılan bir araştırmada Turkish Online Journal of Educational Technology (TOJET) dergisinde 2003- 2007 yılları arasinda yayımlanan eğitim teknolojileri ile ilgili makaleler analiz edilmiştir. Bu analizde, makalelerin araştırma yöntemleri, konuları, veri toplama yöntemleri, kaynakları gibi özelliklerine bakılarak inceleme yapılmıştır. Araştırma sonucunda, nicel araştırma yöntemleriyle daha fazla araştırma yapıldığ1 ve örneklem grubunun daha çok yükseköğretim düzeyinde oluşturulduğu bulunmuştur. Karadağ (2010) tarafından nitel araştırma modelinin kullanılarak yapılan araştırmada ise, Türkiye'de eğitim bilimleri alanında yapılmış doktora tezlerinde kullanılan araştırma modellerinin nitelik düzeyleri ve yapılan analitik hata tipleri belirlenmeye çalışlmıştır. Araştırmanın kuramsal evreni Türkiye'de eğitim bilimleri alanında yapılmış doktora tezlerinden oluşmaktadır. Araştırmada güncellik ve yöntembilim alanındaki gelişmeler dikkate alınarak belirlenen çalışılabilir evren, Türkiye'de eğitim bilimleri alanında son 5 yılda (2003-2007) yapılan 324 doktora tezinden oluşmaktadır. Araştırma sonucunda elde edilen bulgulara göre, eğitim bilimleri alanında yapılan doktora tezlerinde kullanılan araştırma modellerinin nitelik düzeylerinin yeterli düzeyinde olmadığ saptanmıştır. Şimşek ve arkadaşları (2009), Türkiye'de dokuz üniversitede 2000-2009 yılları arasında eğitim teknolojisi alanında yapılan toplam 259 yüksek lisans tezi üzerinde inceleme yapmışlardır. Araştırma sonucunda Türkiye'de eğitim teknolojisi alanındaki çalışmaların genellikle eğitsel teknoloji kullanımı ve bilgisayar destekli öğretim gibi geleneksel birkaç konuda yoğunlaştığını, gerek kullanılan veri toplama araçları, gerek örnekleme yöntemleri, gerekse kullanılan istatistiksel tekniklere bakıldığında yenilikçi araştırmaların yetersiz olduğu araştırmacılar tarafından bulunmuştur. Yalçın, Bilican, Kezer ve Yalçın (2009) tarafından yapılan araştırmada ise, SSCI'da taranan ve Türkiye'de yayımlanan Hacettepe Üniversitesi Eğitim Fakültesi Dergisi'ndeki makalelerin yapıları incelenmiştir. Araştırmada içerik analiz kullanılmıştır. Araştırmanın sonucunda, makalelerde en çok tarama $(\% 42,2)$ türünde araştırmalara yer verildiğini, nicel araştırmaların tüm araştırmalar içinde \% 57,8'lik yer tuttuğunu, en çok kullanılan istatistik teknikleri içinde betimsel istatistik, ANOVA, $\mathrm{t}$ testi, korelasyon tekniklerinin olduğunu bulunmuştur.

Yukarıda verilenler dikkate alındığında, birçok alanda yapılan çalışmaların araştırma konuları, çalışmaların nitelik ve nicelikleri, yöntemleri ve kullanılan teknikleri açısından içerik analizi yöntemiyle değerlendirildiği; böylece belli bir alandaki eğilim tespit edilmeye çalışıldığı görülmektedir. Elde edilen verilerin, eğitim araştırmalarına yön verdiği gibi, eğitim araştırmaların yayın politikalarının geliştirilmesine de önemli katkılar sağlayacağı düşünülmektedir. Türkiye'de eğitim alanında önemli bir yeri olan ve uluslar arası indeksler tarafından dizinlenen (SSCI) "Eğitim ve Bilim" dergisinde yayınlanan makalelerin, eğitim araştırmalarına önemli katkı sağladığı hatta yönlendirici rolü olduğu söylenebilir. Bu aşamada ise, "Eğitim ve Bilim" dergisinde yayınlanan makalelerin eğitim araştırmalarında ne tür eğilim gösterdiği, eğitim alanına konu, yöntem, içerik gibi yapılarda hangi verileri sağladığı görülmesi gerekmektedir. Bu anlamda "Eğitim ve Bilim" dergisinde yayınlanan araştırmaların, kapsamlı ve bütüncül bir şekilde değerlendirilmesi için böyle bir araştırmaya ihtiyaç olduğu söylenebilir.

\section{Yöntem}

$\mathrm{Bu}$ araştırma betimsel tarama modelinde bir araştırmadır. Betimsel araştırmalar; olayların, objelerin, varlıkların, kurumların, grupların ve çeşitli alanların ne olduğunu betimlemeye, açıklamaya çalışır. Bu sayede onları iyi anlayabilme, gruplayabilme olanağı sağlanır ve aralarındaki ilişkiler saptanmış olur (Kaptan, 1998). Betimsel tarama modelinde bilimin gözlem, kaydetme, olaylar arasındaki ilişkileri tespit etme ve kontrol edilen değişmez ilkeler üzerinde genellemelere varma nitelikleri söz konusudur. Yani bilimin tasvir fonksiyonu ön plandadır (Yıldırım ve Şimşek, 2006). Yapılan bu çalışmada da Eğitim ve Bilim dergisinde 2007-2013 yılları arasında yayınlanan makaleler çeşitli değişkenler açısından analiz edilerek açıklanmaya çalışılmıştır. Yapılan çalışmada analiz edilen makalelerin Eğitim ve Bilim dergisinin SSCI tarafından dizinlendiği (32. Cilt, 143. Sayı) 2007 tarihinden 2013 yılı son sayısına kadar olması araştırmanın sınırlılığını oluşturmaktadır. 


\section{Veri Toplama Araci}

Eğitim ve Bilim dergisindeki makalelerin analizini yapmak için Göktaş ve diğerleri (2012) tarafından kullanılan ve orijinali Sözbilir, Kutu ve Yaşar (2012) tarafından geliştirilen "Yayın Sınıflama Formu" kullanılmıştır. Aynı form Kılıç-Çakmak ve diğ (2013) tarafından da kullanılmıştır. Her üç çalışmada eğitim bilimleri ve alt alanlarına ilişkin makaleleri tasnif etmek için kullanılan bu form üzerinde bir takım değişiklikler yapılmıştır. Eğitim bilimleri alanında yapılan araştırmaların tamamını kapsayacak şekilde düzenlenen form bu haliyle araştırmacılar tarafından revize edilerek kullanılmıştır. Yayın sınıflama formu, makalenin kimliği hakkında tanımlayıcı bilgi, disiplin alanı, makalenin konusu, yöntemi, veri toplama araçları, örneklemi ve veri analiz yöntemleri şeklinde yedi bölümden oluşmaktadır. Eğitim ve Bilim dergisi 2009 yılı 153. Sayısından rastgele seçilen 9 makale araştırmacılar tarafından birlikte sınıflandırılmıştır. Daha sonra araştırmacılar rastgele 5 makale belirleyerek bağımsız olarak seçtikleri makaleleri sınıflandırmışlardır. Araştırmacılar tarafından sınıflandırılan makaleler güvenirliği artırmak amacıyla grup içerisinde tartışılıp sınıflandırmalar üzerindeki anlaşmazlıklar çözümlenmiştir.

\section{Verilerin Analizi}

Bu çalışmada, elde edilen verilerin değerlendirilmesinde içerik analizi tekniği kullanılmıştır. 2007-2013 yılları arasında Eğitim ve Bilim dergisinde yayınlanan makaleler tasnif edilerek yedi temel kategori altında analiz edilmiştir. İçerik analizinde temel amaç, toplanan verileri açıklayabilecek kavramalara ve ilişkilere ulaşmaktır. Betimsel analizde özetlenen ve yorumlanan veriler, içerik analizinde daha derin bir işleme tabi tutulur ve betimsel yaklaşımla fark edilemeyen kavram ve temalar bu analiz sonucu keşfedilebilir. İçerik analizinde temelde yapılan işlem, birbirine benzeyen verileri belirli kavramlar ve temalar çerçevesinde bir araya getirmek ve bunları okuyucunun anlayabileceği bir biçimde organize ederek yorumlamaktır (Yıldırım ve Şimşek, 2006). Falkingham ve Reeves (1998) de içerik analizinin, yayın yığınlarının değerlendirilmesi için kullanılan yeni bir yöntem olduğunu ifade etmiştir. Eğitim ve bilim dergisinde yer alan ve tasnifi yapılan makalelerin analiz edilmesi ve yorumlanması sürecinde: adlandırma, kategori geliştirme, geçerlik ve güvenirliğin sağlanma, frekansların hesaplanması ve yorumlama aşamalarına dikkat edilmiştir. Yapılan içerik analizinin adlandırma ve kategori geliştirme aşamasında; makalelerin her biri dikkatlice incelenmiş ve disiplin alanı, konusu, yöntemi, veri toplama araçları, örneklemi ve veri analiz yöntemleri gibi kategoriler altında tasnif edilmiştir. Geçerlik ve güvenirliğin sağlanmasında değerlendirilen makalelerin araştırmacıların görüş birliğine dayalı olarak analiz edilmesine dikkat edilmiştir. Son olarak analiz edilen makalelerin belirlenen kategorilere dayalı bir şekilde tekrarlanma sıklıkları ve yüzdeleri hesaplanmış ve bu bilgilere dayalı bir şekilde yorumlanmaya çalışılmıştır. Araştırmacılar tarafından analizi yapılan makaleler; makalenin disiplin alanı, konusu, yöntemi, veri toplama araçları, örneklemi ve veri analiz yöntemleri konusunda analiz edilmiştir. Bu işlemler sırasında her bir araştırmacı incelediği makale ile ilgili genel bir değerlendirme yapmıştır. Öncelikle makalenin cilt, sayı ve yazarlarına ilişkin bilgiler veri olarak girilmiş, yayın dili, yazarın çalıştığı kurum bilgileri ve makalenin referans sayılarına ilişkin veri girişi yapılmıştır. Daha sonra, makalenin konusu ve yöntemi tespit edilmiş, makalede kullanılan veri toplama araç türü, verileri analiz ederken kullanılan yöntemler tespit edilmiştir. Ancak bu aşamalarda bazı makalelerde özellikle araştırmanın yöntemi, veri toplama araç türü ve veri analiz yöntemlerinde açıklayıcı bilgilerin olmadığ görülmüştür. Bu durumda araştırmacılar tarafından makalenin yöntemi, veri toplama araç türü ve veri analiz yöntemleri araştırmaya uygun bir şekilde adlandırılıp kodlanarak analiz edilmiştir. Bu tür bilgilerin yeniden adlandırıldığı makalelerde araştırmacıların görüş birliğine dikkat edilmiştir.

\section{Bulgular}

Araştırmanın bulgular bölümünde, TED Eğitim ve Bilim dergisinde yayınlanan makalelerin farklı değişkenler açısından yapılan analizleri ve elde edilen bulgular bulunmaktadır. Bu bağlamda sırasıyla; üniversitelere göre dağılım, kullanılan değişken sayısı, yayın dili, işlem basamaklar, konu alanı, kullanılan yöntemler, veri toplama araçları, örneklem, verilerin analiz yöntemi, öneriler ve tartışma açısından araştırma bulgularına bu bölümde verilmiştir. Araştırma bulguları, frekans ve yüzdelik sonuçları şeklinde tablolaştırılmış ve tablo yorumları yapılmıştır. 
Tablo 1.

TED Ĕ̆itim ve Bilim Dergisinde Yayınlanan Makalelerin Üniversitelere Göre Dağılımı

\begin{tabular}{|c|c|c|}
\hline Üniversiteler & $\begin{array}{l}\text { Frekans } \\
\text { (f) }\end{array}$ & $\begin{array}{c}\text { Yüzdelik } \\
(\%)\end{array}$ \\
\hline Hacettepe Üniversitesi & 80 & 14.6 \\
\hline Ankara Üniversitesi & 46 & 8.4 \\
\hline Gazi Üniversitesi & 42 & 7.7 \\
\hline ODTÜ & 32 & 5.8 \\
\hline Abant İzzet Baysal Üniversitesi & 20 & 3.6 \\
\hline Anadolu Üniversitesi & 14 & 2.6 \\
\hline Dokuz Eylül Üniversitesi & 14 & 2.6 \\
\hline Karadeniz Teknik Üniversitesi & 14 & 2.6 \\
\hline MEB & 13 & 2.4 \\
\hline Ege Üniversitesi & 12 & 2.2 \\
\hline Mersin Üniversitesi & 11 & 2 \\
\hline Pamukkale Üniversitesi & 11 & 2 \\
\hline Firat Üniversitesi & 10 & 1.8 \\
\hline Çanakkale Onsekiz Mart Üniversitesi & 9 & 1.6 \\
\hline Marmara Üniversitesi & 9 & 1.6 \\
\hline Sakarya Üniversitesi & 9 & 1.6 \\
\hline Akdeniz Üniversitesi & 7 & 1.3 \\
\hline Boğaziçi Üniversitesi & 7 & 1.3 \\
\hline Erciyes Üniversitesi & 7 & 1.3 \\
\hline Kocaeli Üniversitesi & 7 & 1.3 \\
\hline Mehmet Akif Ersoy Üniversitesi & 7 & 1.3 \\
\hline Başkent Üniversitesi & 6 & 1.1 \\
\hline Çukurova Üniversitesi & 6 & 1.1 \\
\hline İnönü Üniversitesi & 6 & 1.1 \\
\hline Osmangazi Üniversitesi & 6 & 1.1 \\
\hline Yıldız Teknik Üniversitesi & 6 & 1.1 \\
\hline Ahi Evran Üniversitesi & 5 & .9 \\
\hline Atatürk Üniversitesi & 5 & .9 \\
\hline Balıkesir Üniversitesi & 5 & .9 \\
\hline Gaziosmanpaşa Üniversitesi & 5 & .9 \\
\hline Kırıkkale Üniversitesi & 4 & .7 \\
\hline Muğla Üniversitesi & 4 & .7 \\
\hline Niğde Üniversitesi & 4 & .7 \\
\hline Ondokuz Mayıs Üniversitesi & 4 & .7 \\
\hline Adıyaman Üniversitesi & 3 & .5 \\
\hline Adnan Menderes Üniversitesi & 3 & .5 \\
\hline Bahçeşehir Üniversitesi & 3 & .5 \\
\hline Cumhuriyet Üniversitesi & 3 & .5 \\
\hline Dumlupınar Üniversitesi & 3 & .5 \\
\hline Erzincan Üniversitesi & 3 & .5 \\
\hline Gaziantep Üniversitesi & 3 & .5 \\
\hline İstanbul Üniversitesi & 3 & .5 \\
\hline Selçuk Üniversitesi & 3 & .5 \\
\hline TED Üniversitesi & 3 & .5 \\
\hline Uludağ Üniversitesi & 3 & .5 \\
\hline Diğer Üniversiteler & 68 & \\
\hline Toplam & 548 & 100 \\
\hline
\end{tabular}




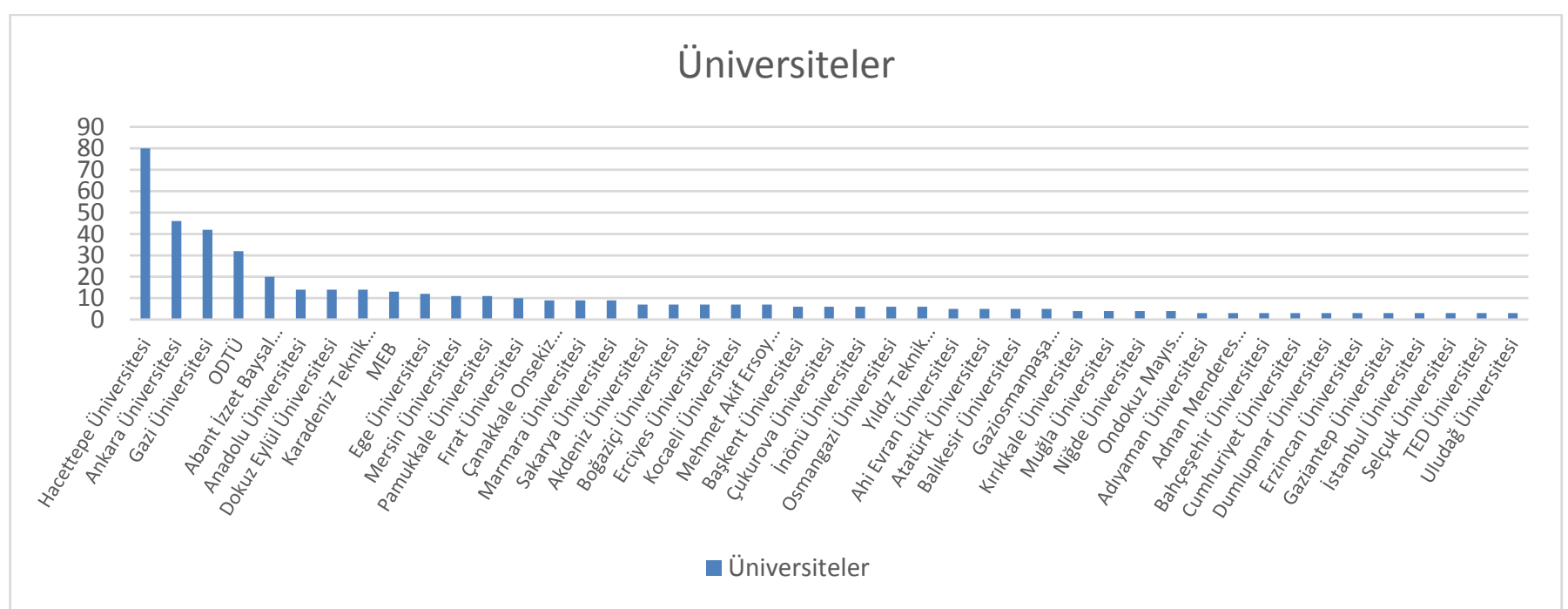

Şekil 1. TED Eğitim ve Bilim Dergisinde Yayınlanan Makalelerin Üniversitelere Göre Dağılımı

Yukarıdaki tablo incelendiğinde, TED Eğitim ve Bilim dergisinde yayınlanan makalelerin 548 üniversiteden geldiği görülmektedir. Bazı makalelerin birden çok kişi tarafından gönderilmesi burada dikkate alınmıştır. Aynı zamanda, 3 makalenin (\% 5) altındaki bulgular "Diğer Üniversiteler" bölümüne alınmıştır. Tabloda, TED Eğitim ve Bilim dergisinde yayınlanan makalelerin üniversite dağılımları görünmektedir. Buna göre, Hacettepe Üniversitesi, Eğitim ve Bilim Dergisinde en fazla yayın yapan üniversite olduğu görülmektedir. Hacettepe Üniversitesi adına, Eğitim ve Bilim Dergisinde 80 makale yayınlandığı görülmektedir. Bu oran dergide yayınlanan makalelerin \%14. 6'sını oluşturmaktadır. Hacettepe Üniversitesi'nden sonra en fazla yayın yapan üniversiteler sırasıyla; Ankara Üniversitesi (46), Gazi Üniversitesi (42), ODTÜ (32) ve Abant İzzet Baysal (20) olduğu görülmektedir. Beş üniversitede adına yapılan yayınların toplamı 220 olduğu, yani dergide yapılan yayınların \%40.1'ini oluşturduğu görülmektedir. Aynı zamanda, MEB kaynaklı makalelerinden önemli bir orana (\% 2.4) sahip olduğu görülmektedir.

Tablo 2

TED Eğitim ve Bilim Dergisinde Yayınlanan Makalelerde Kullanılan Değişken Sayısı Dağılımı

\begin{tabular}{lcc}
\hline Değişken Sayısı & $\begin{array}{c}\text { Frekans } \\
(\mathrm{f})\end{array}$ & $\begin{array}{c}\text { Yüzdelik } \\
(\%)\end{array}$ \\
\hline 1 & 258 & 52.4 \\
2 & 154 & 31.3 \\
3 & 64 & 13 \\
4 & 11 & 2.2 \\
5 ve daha fazla & 5 & 1 \\
Toplam & 490 & 100 \\
\hline
\end{tabular}




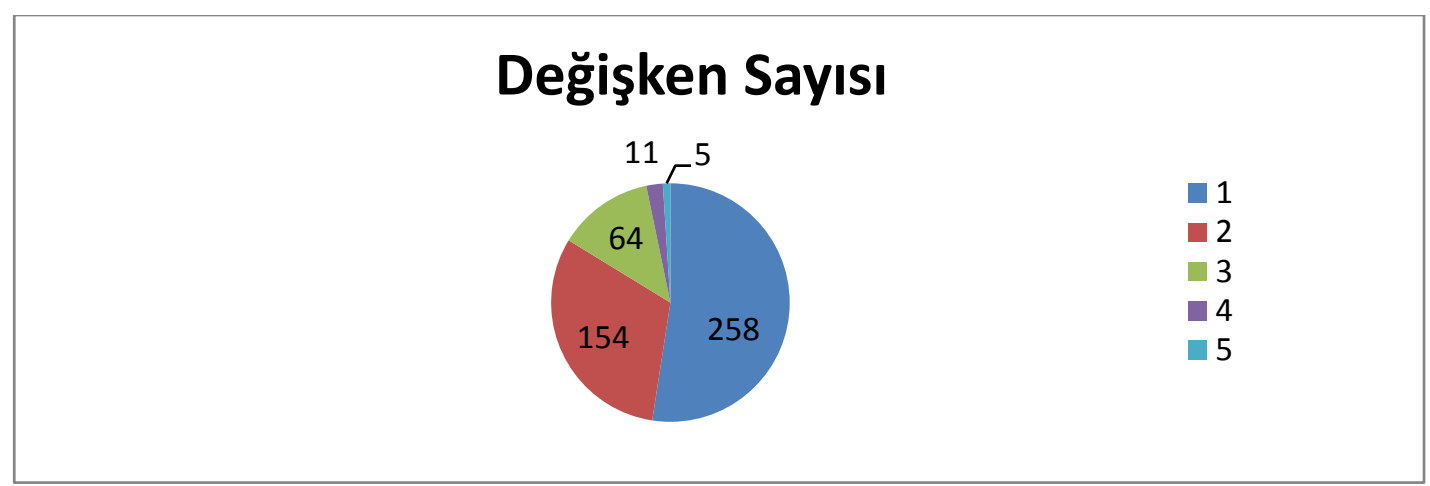

Şekil 2. TED Eğitim ve Bilim Dergisinde Yayınlanan Makalelerde Kullamılan Değişken Sayısı Dağılımı

Yukarıdaki tablo ve şekil incelendiğinde, TED Eğitim ve Bilim dergisinde yayınlanan makalelerde kullanılan değişken sayılarına ilişkin betimsel bilgiler bulunmaktadır. Burada, makaledeki temel değişkenler dikkate alınmıştır. Tablo incelendiğinde, 1 ana değişkenin araştırıldığı araştırma ya da makale sayısının 258 olduğu ve bu oranın toplam makalelerin \%52.4'ünü oluşturduğu görülmektedir. Araştırmada, 5 ve daha fazla değişkenin kullanıldığı makale ya da araştırmaların 5 olduğu bulunmuştur.

Tablo 3.

TED Ĕ̆̈itim ve Bilim Dergisinde Yayınlanan Makalelerin Yayın Dili Dağılımı

\begin{tabular}{lcc}
\hline Yayın Dili & $\begin{array}{c}\text { Frekans } \\
(\mathrm{f})\end{array}$ & $\begin{array}{c}\text { Yüzdelik } \\
(\%)\end{array}$ \\
\hline Türkçe & 320 & 65 \\
İngilizce & 172 & 35 \\
Toplam & 492 & 100 \\
\hline
\end{tabular}

\section{Yayın Dili}

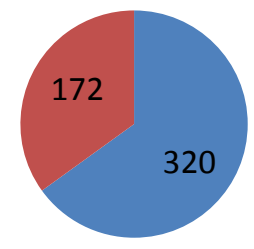

- Türkçe

İngilizce

Şekil 3. TED Eğitim ve Bilim Dergisinde Yayınlanan Makalelerin Yayın Dili Dă̆ılımı

Yukarıdaki tabloda ve şekilde, TED Eğitim ve Bilim dergisinde yayınlanan makaleler yayın diliyle ilgili bilgilere yer verilmiştir. Tablo incelendiğinde, dergide yayınlanan makalelerin 320 (\%65)'sinin Türkçe ve 172 (\%35) 'sinin ise İngilizce olduğu görülmektedir. 
Tablo 4.

TED Eğitim ve Bilim Dergisinde Yayınlanan Makalelerin İşlem Basamakları Dağılımı

\begin{tabular}{lcc}
\hline İşlem Basamakları & $\begin{array}{c}\text { Frekans } \\
(\mathrm{f})\end{array}$ & $\begin{array}{c}\text { Yüzdelik } \\
(\%)\end{array}$ \\
\hline Yok & 234 & 47.6 \\
Var & 258 & 52.4 \\
Toplam & 492 & 100 \\
\hline
\end{tabular}

\section{İşlem Basamakları}

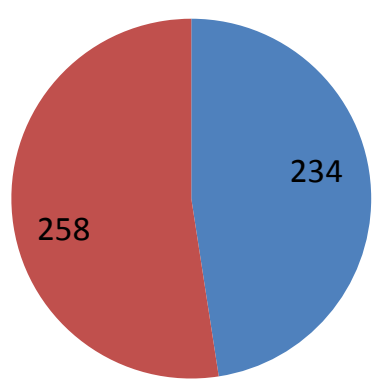

Yok

- Var

Şekil 4. TED Ĕ̆itim ve Bilim Dergisinde Yayınlanan Makalelerin İşlem Basamakları Dağılımı

Yukarıdaki tabloda ve şekilde, TED Eğitim ve Bilim dergisinde yayınlanan makalelerde işlem basamaklarıyla ilgili bilgilere yer verilmiştir. Tablo incelendiğinde, dergide yayınlanan makalelerin 234 (\%47.6)'ünde işlem basamakları hakkında bilgi verilmediği; 258 (\%52,4)'inde ise işlem basamaklarının olduğu görülmektedir. Buna göre, makalelerin önemli bir kısmında, veri toplama süreciyle ilgili ayrıntılı ve işlevsel bilgiye yer verilmediği söylenebilir. 
Tablo 5 .

TED Eğitim ve Bilim Dergisinde Yayınlanan Makalelerin Konu Alanı Dağılımı

\begin{tabular}{lcc}
\hline Konu Alanı & $\begin{array}{c}\text { Frekans } \\
(\mathrm{f})\end{array}$ & $\begin{array}{c}\text { Yüzdelik } \\
(\%)\end{array}$ \\
\hline Eğitim Yönetimi & 56 & 11.4 \\
Eğitim Psikolojisi & 55 & 11.2 \\
Eğitim Programları ve Öğretim & 61 & 12.4 \\
Ölçme değerlendirme & 44 & 8.9 \\
PDR & 41 & 8.3 \\
Özel Ĕ̆itim & 9 & 1.8 \\
Eğitim Bilimleri Diğer Alanlar & 20 & 3 \\
Okul Öncesi & 33 & 6.7 \\
Okuma yazma ve Türkçe Öğretimi & 10 & 2 \\
Matematik Öğretimi & 55 & 11.2 \\
Fen Bilgisi Öğretimi & 27 & 5.5 \\
Fizik öğretimi & 5 & 1 \\
Kimya Öğretimi & 6 & 1.2 \\
Biyoloji Öğretimi & 4 & .8 \\
Tarih Öğretimi & 6 & 1.2 \\
Felsefe Öğretimi & 1 & .2 \\
Alan Eğitimi Diğer & 50 & 10.1 \\
Diğer Alanlar & 15 & 3 \\
Toplam & 492 & 100 \\
\hline
\end{tabular}

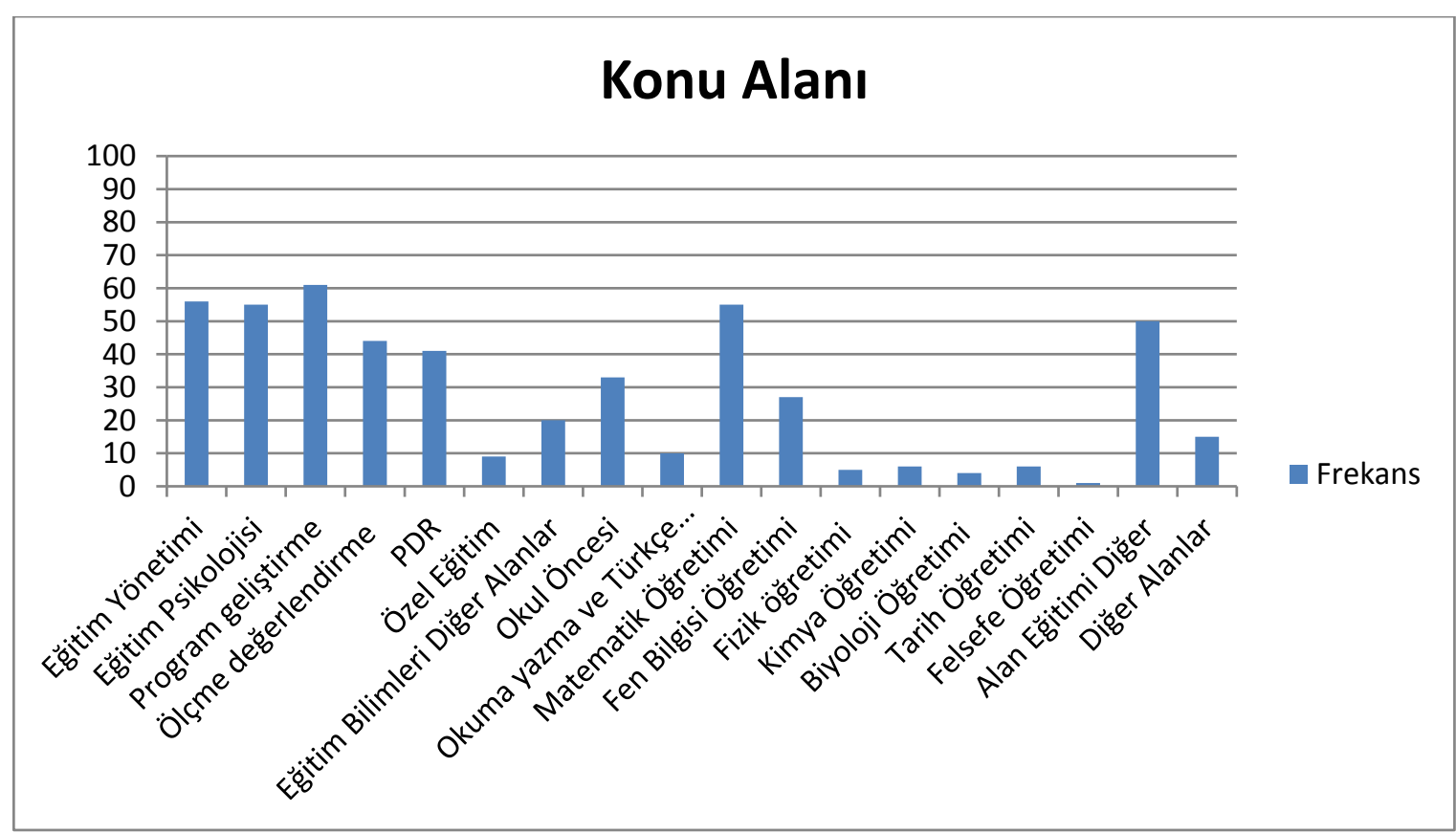

Şekil 5. TED Ĕ̆gitim ve Bilim Dergisinde Yayınlanan Makalelerin Konu Alanı Dağılımı

Yukarıdaki tablo ve şekilde, TED Eğitim ve Bilim dergisinde yayınlanan makalelerin konu alan dağılımı ile ilgili bulgulara yer verilmiştir. Bulgular incelendiğinde, 61 yayınla (\%12.4) en fazla program geliştirme ve öğretimi alanında yayın alanında yapıldığı görülmektedir. Program geliştirme 
alanından sonra, en fazla yayın yapan alanlar sırasıyla; Eğitim Yönetimi (56), Eğitim Psikolojisi(55), Matematik Eğitimi(55), Diğer Alan Eğitimleri (50) ve Ölçme Değerlendirme (44) olduğu görülmektedir. Alan Eğitiminde matematik eğitiminden sonra en fazla okul öncesi (33) ve Fen Bilgisi Öğretiminden (27) makale yayınlandığı diğer önemli bir bulgudur. Aynı zamanda Eğitim Bilimleri alanında 296 makale yayınlanırken, Alan Eğitiminden 197 makale ve diğer alanlardan 15 makalenin yayınlandığı görülmektedir. Araştırmada bulunan konu alanıyla ilgili diğer frekans ve yüzdelere tabloda yer verilmiştir.

Tablo 6.

TED Ĕ̆itim ve Bilim Dergisinde Yayınlanan Makalelerin Yöntem Dağılımı

\begin{tabular}{lcc}
\hline Makalenin Yöntemi & $\begin{array}{c}\text { Frekans } \\
(\mathrm{f})\end{array}$ & $\begin{array}{c}\text { Yüzdelik } \\
(\%)\end{array}$ \\
\hline Nicel & 377 & 69.5 \\
Nitel & 73 & 22 \\
Karma & 13 & 2.6 \\
Alanyazın Derleme & 26 & 5.3 \\
Diğer & 3 & 0.6 \\
Toplam & 492 & 100 \\
\hline
\end{tabular}

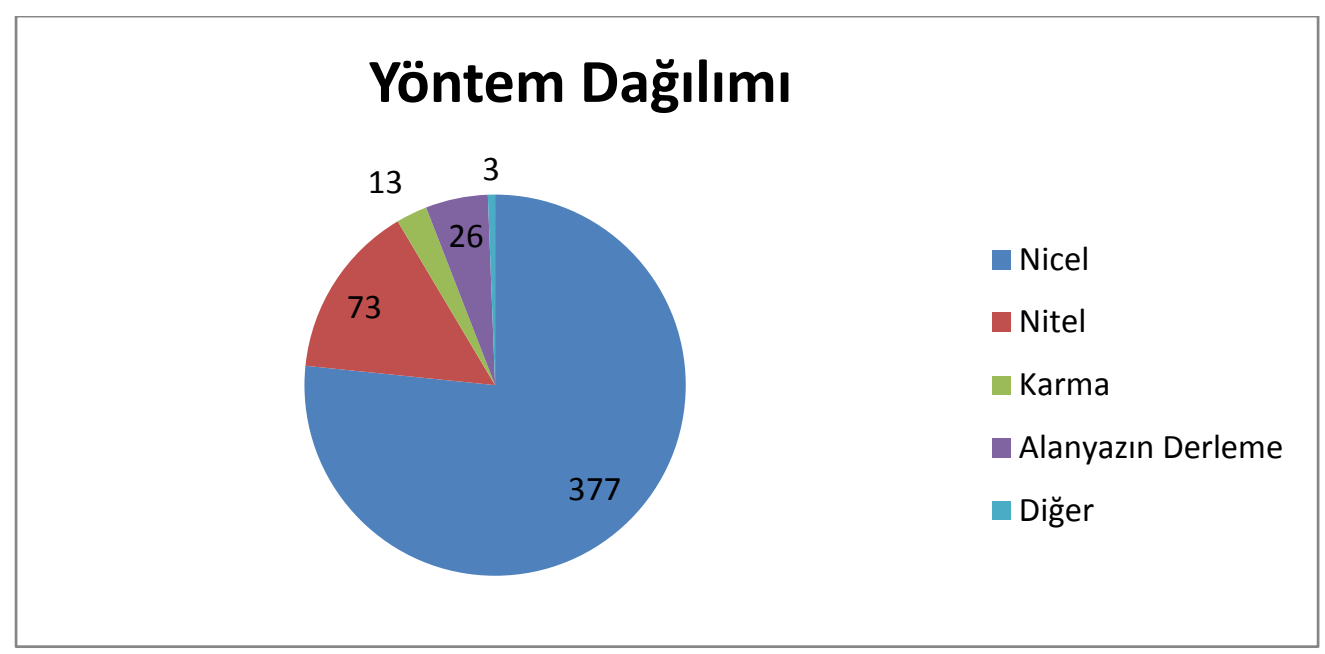

Şekil 6. TED Eğitim ve Bilim Dergisinde Yayınlanan Makalelerin Yöntem Dağılımı

Yukarıdaki tablo ve şekilde, TED Eğitim ve Bilim dergisinde yayınlanan makalelerin yöntem dağılımı ile ilgili bulgulara yer verilmiştir. Bulgular incelendiğinde, nicel araştırmaların daha fazla yayınladığı (377) ve nicel araştırmaların, toplam yüzdeye göre önemli bir yüzdeye (69.5) sahip olduğu bulunmuştur. Aynı zamanda araştırmada, çalışmaların \% 22'sinin nitel araştırma yöntemini; \%5.3'ünün Alanyazın derleme araştırma yöntemini kullandığ 1 ; \%2.6'sının ise karma yöntemi kullandığı bulunmuştur. Kullanılan yöntemin daha detaylı açıklamasına ilişkin bulgulara aşağıdaki tabloda yer verilmiştir. 
Tablo 7.

TED Ĕ̆itim ve Bilim Dergisinde Yayınlanan Makalelerin Yöntem Açıklama Dağılımı

\begin{tabular}{llcc}
\hline Yöntem Açıklama & & Frekans & Yüzdelik \\
& & $(\mathrm{f})$ & $(\%)$ \\
\hline \multirow{3}{*}{ Nicel Deneysel } & Tam Deneysel & 35 & 7.1 \\
& Yarı Deneysel & 14 & 2.8 \\
& Zayıf & 1 & 0.2 \\
& Tek Denekli & 1 & 0.2 \\
\hline \multirow{4}{*}{ Nicel Deneysel Olmayan } & Betimsel & 226 & 45.9 \\
& Karşılaştırmalı & 7 & 1.4 \\
& Korelasyonel & 12 & 2.4 \\
& Tarama & 32 & 6.5 \\
& Ölçek Geliştirme & 49 & 10 \\
\hline \multirow{4}{*}{ Nitel } & Kültür Analizi & 3 & .6 \\
& Olgu Bilim & 35 & 7.1 \\
& Kuram Oluşturma & 1 & .2 \\
& Örnek Olay & 25 & 5.1 \\
& Tarihsel Analiz & 1 & .2 \\
& Kavram Analizi & 2 & .4 \\
& Eylem Araştırması & 6 & 1.2 \\
\hline \multirow{3}{*}{ Karma } & Açıklayıcı (Nicel) & 9 & 1.8 \\
& Açıklayıcı (Nitel) & 3 & .6 \\
\hline \multirow{2}{*}{ Alanyazın Derleme } & Çeşitleme & 1 & .2 \\
\hline Diğer & Meta Analizi & 1 & .2 \\
\hline Toplam & Alanyazın & 25 & 5.1 \\
\hline & Diğer & 3 & .6 \\
\hline
\end{tabular}

Tablo incelendiğinde, nicel yöntem kullanan araştırmaların, 294'ü deneysel olmayan yöntemi, 51'i ise deneysel modeli tercih ettiği görülmektedir. Araştırma bulguları incelendiğinde, deneysel olmayan araştırma yönteminde, betimsel modelin en fazla tercih edilen model olduğunu (226) bulunmuştur. Aynı zamanda betimsel araştırma yönteminin bütün araştırmalarda en fazla tercih edilen model olduğunu (226), tüm araştırma yöntemleri arasında \%45.9 oranında tercih edildiği görülmektedir. Deneysel olmayan nicel yöntemlerden ölçek geliştirme yönteminin ikinci olarak tercih edilen nicel yöntem olduğu (49) araştırmanın diğer bir bulgusudur. Araştırmada, deneysel yöntemlerden tam deneysel yöntemin diğer deneysel yöntemlere göre daha fazla tercih edildiği (35) bulunmuştur. Araştırmada en az tercih edilen deneysel yöntemlerin zayıf (1)ve tek denekli(1) olduğu bulunmuştur.

Araştırma sonuçları incelendiğinde, TED Eğitim ve Bilim Dergisinde çıkan makalelerin 73'ü nitel araştırma yöntemiyle yazıldığı bulunmuştur. Araştırmada nitel araştırma yöntemlerinden, olgu bilim yönteminin en fazla tercih edilen yöntem olduğu(35, \%7.1) görülmektedir. Olgu bilim yönteminden sonra örnek olay yöntemi en fazla tercih edilen diğer nitel araştırma yöntemi (25, \%5.1)olduğu araştırmada çıkan önemli bir bulgudur. Araştırmada nitel araştırma yöntemlerinden, kuram oluşturma $(\% .02)$ ve analiz yöntemlerinin (\%.02) en az kullanılan nitel yöntemler olduğu bulunmuştur. Araştırmada, karma yöntemlerinin kullanım sıklığının diğer yöntemleri göre daha az olduğu görülmektedir. Araştırmada, 12 makalede karma yöntemin kullanıldığı ve bunlardan, 9 makalede açıklayıcı nicel karma yöntem tercih edildiği bulunmuştur. Araştırmada çeşitlemeye dayalı karma yöntemin en az tercih edilen karma yöntem olduğu bulunmuştur.

Araştırma sonuçlarına bakıldığında, alanyazın derleme yöntemlerinin kullanıldığı makale sayısının 26 olduğu görülmektedir. Aynı zamanda 26 çalışmanın 25'i derleme ya da literatür taraması 
yöntemini kullanmıştır. Bu bölümde meta-analiz çalışmasının ise sadece 1 çalışmada kullanıldığı görülmüştür. $\mathrm{Bu}$ yöntemlerin dışında diğer araştırma yöntemlerinin çok az (3) kullanıldığı araştırmanın diğer bir bulgusudur.

Tablo 8.

TED Ĕ̆itim ve Bilim Dergisinde Yayınlanan Makalelerde Kullanılan Veri Toplama Araçları Dağılımı

\begin{tabular}{lcc}
\hline Veri Toplama Araçları & $\begin{array}{c}\text { Frekans } \\
(\mathrm{f})\end{array}$ & $\begin{array}{c}\text { Yüzdelik } \\
(\%)\end{array}$ \\
\hline Gözlem & 11 & 2.4 \\
Görüşme & 50 & 9.9 \\
Başarı Testleri & 31 & 6.2 \\
Tutum, Alg1, Kişilik Testleri & 257 & 51 \\
Anket & 77 & 15.3 \\
Doküman & 45 & 8.9 \\
Alternatif Araçlar & 28 & 5.6 \\
Diğer & 4 & .8 \\
Toplam & 504 & 100 \\
\hline
\end{tabular}

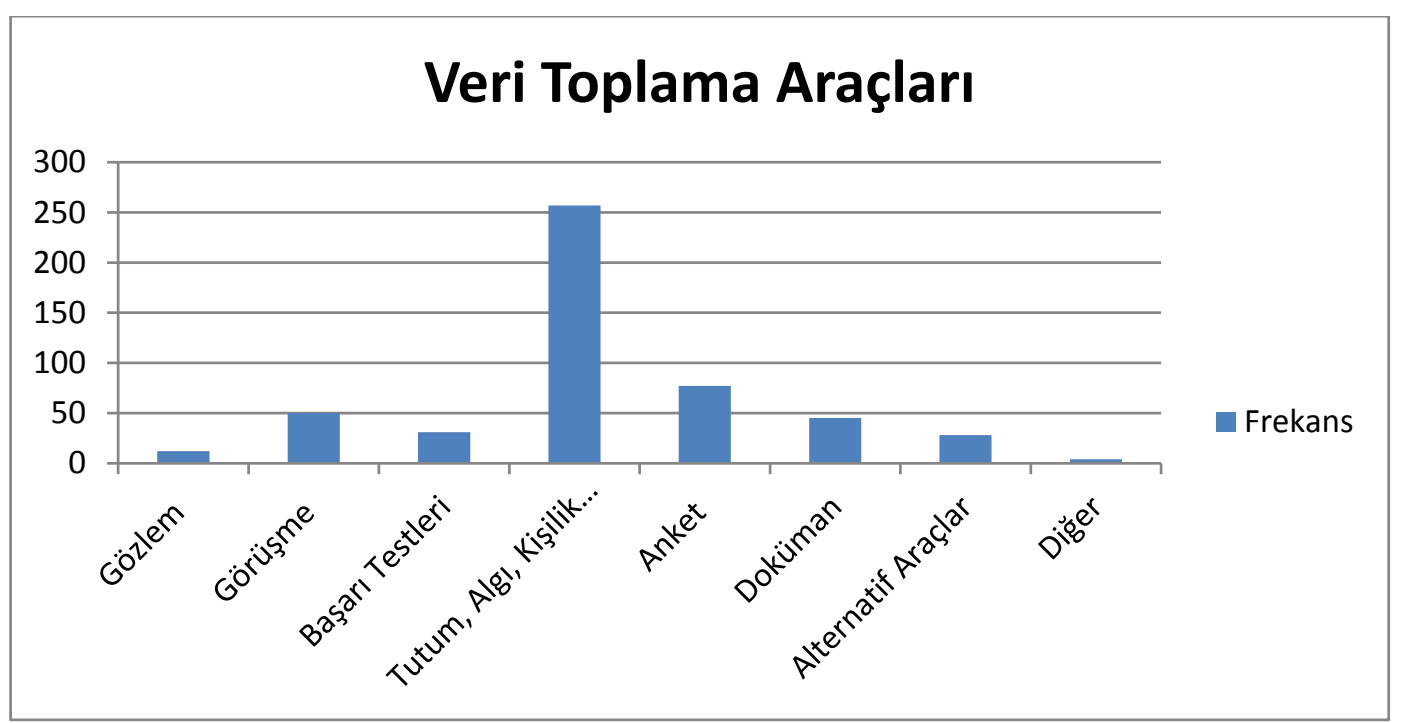

Şekil 7. TED Eğitim ve Bilim Dergisinde Yayınlanan Makalelerde Kullanılan Veri Toplama Araçları

Yukarıdaki tabloda, TED Eğitim ve Bilim dergisinde yayınlanan makalelerin veri toplama araçları dağılımı ile ilgili bulgulara yer verilmiştir. Bulgular incelendiğinde, tutum, kişilik, algı testlerinin daha fazla kullanıldığı (257) ve toplam yüzdeye göre önemli bir yüzdeye (\% 51) sahip olduğu bulunmuştur. Aynı zamanda araştırmada, ankete dayalı çalışmaların, testlerden sonra en fazla tercih edilen veri toplama aracı olduğu görülmektedir. Araştırma sonucuna göre, makalelerde kullanılan 504 veri toplama aracından, $77^{\prime}$ si anket olduğu görülmektedir. Araştırmada, diğer veri toplama araçlarının (4) ve gözlem (12) en az tercih edilen yöntemler olduğu bulunmuştur. Kullanılan veri toplama araçlarına daha detaylı açıklamasına ilişkin bulgulara aşağıdaki tabloda yer verilmiştir. 
Tablo 9.

TED Eğitim ve Bilim Dergisinde Yayınlanan Makalelerde Kullanılan Veri Toplama Araçları Açıklama Dağı̆lımı

\begin{tabular}{llcc}
\hline Veri Toplama Araçları Açıklama & & $\begin{array}{c}\text { Frekans } \\
(\mathrm{f})\end{array}$ & $\begin{array}{c}\text { Yüzdelik } \\
(\%)\end{array}$ \\
\hline Gözlem & & 11 & 2.2 \\
\hline Görüşme & Yapılandırılmış & 24 & 4.8 \\
& Yarı Yapılandırılmış & 27 & 5 \\
& Diğer & 3 & .6 \\
\hline Başarı Testleri & Açı Uçlu & 3 & .6 \\
& Çoktan Seçmeli & 23 & 4.6 \\
& Diğer & 6 & 1.2 \\
\hline Tutum, Algı, Kişilik Testleri & Açk Uçlu & 16 & 3.2 \\
& Çoktan Seçmeli & 8 & 1.6 \\
& Likert & 204 & 40.5 \\
& Diğer & 28 & 5.6 \\
\hline Anket & Açık Uçlu & 29 & 5.8 \\
& Çoktan Seçmeli & 1 & .2 \\
& Likert & 26 & 5.2 \\
& Diğer & 11 & 2.2 \\
\hline Doküman & & 45 & 8.9 \\
\hline Alternatif Araçlar & Perfomans, Tanılayıcı, & 16 & 3.2 \\
& Portfolyo vb. & & \\
& Veri Tabanı Kaynakları & 17 & 3.4 \\
\hline Diğer & & 4 & .8 \\
\hline Toplam & & 504 & 100 \\
\hline
\end{tabular}

Tablo incelendiğinde, makalelerin, çoğunluğunun tutum, alg1 ve kişilik testlerini veri toplama aracı olarak tercih ettikleri görülmektedir. Bu veri toplama aracında, likert tipi araçlar en fazla tercih edilen araçlar olduğu araştırmada bulunmuştur (204). Araştırma sonuçlarına göre, testlerden sonra en fazla tercih edilen veri toplama araçlarının, anket ve görüşme olduğu görülmektedir. Anketlerde, açı uçlu anketlerinin (29) ve likert anketlerinin (26) tercih edildiği araştırmanın bulgularındandır. Araştırma sonuçlarına göre, görüşmelerden en fazla yarı yapılandırılmış görüşme (27); başarı testlerinden, en fazla çoktan seçmeli testlerin (23); alternatif araçlardan en fazla veri tabanlı kaynakların (17) kullanıldığı bulunmuştur. Aynı zamanda araştırmalarda önemli oranda dokümanların veri toplama aracı (45) olarak kullanıldığı görülmektedir.

Tablo 10.

TED Eğitim ve Bilim Dergisinde Yayınlanan Makalelerin Veri Toplama Araç Türü Dağılımı

\begin{tabular}{lcc}
\hline Veri Toplama Araç Türü & $\begin{array}{c}\text { Frekans } \\
(\mathrm{f})\end{array}$ & $\begin{array}{c}\text { Yüzdelik } \\
(\%)\end{array}$ \\
\hline Klasik & 476 & 97.1 \\
Online & 13 & 2,7 \\
Karma & 1 & 0.2 \\
Toplam & 490 & 100 \\
\hline
\end{tabular}




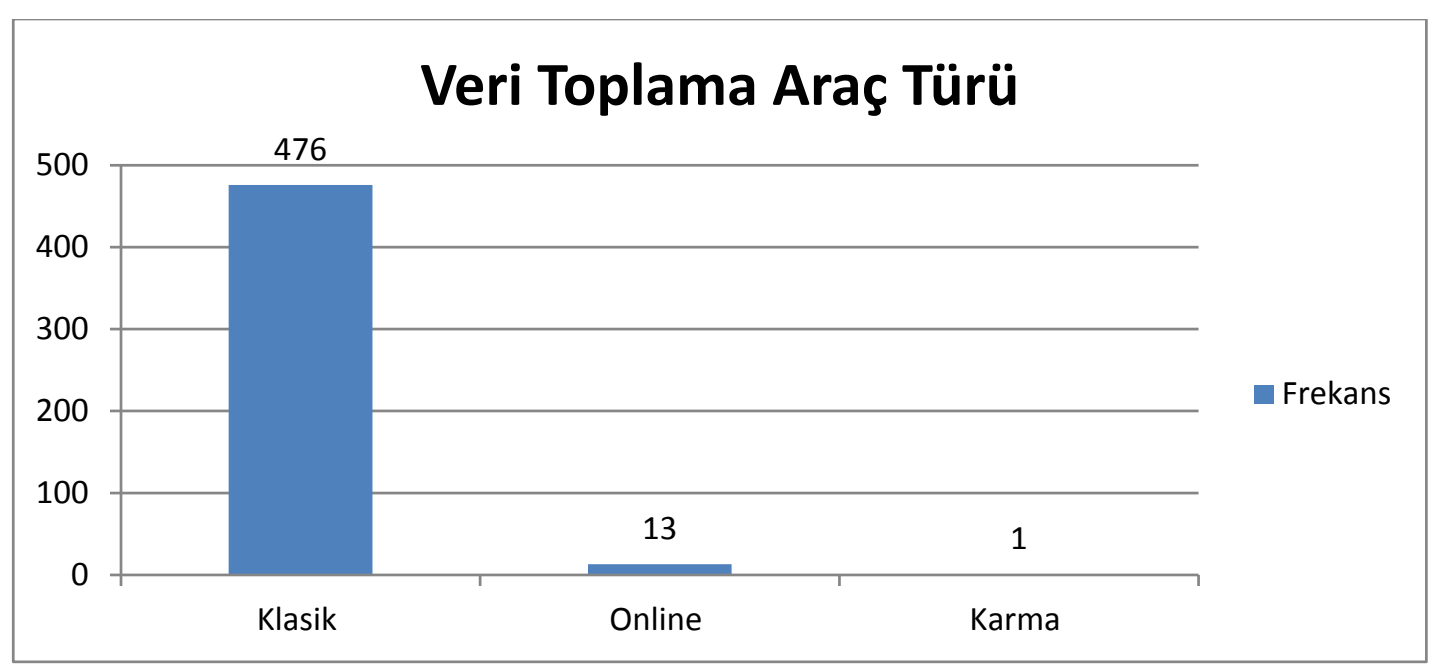

Şekil 8. TED Eğitim ve Bilim Dergisinde Yayınlanan Makalelerin Veri Toplama Araç Türü Dağılımı

Tablo 10'a bakıldığında, TED Eğitim ve Bilimde yayınlanan makalelerin veri toplama araç türleri hakkında betimsel bulgular yer almaktadır. Bulguya göre, 490 makalenin veri toplama araç türü hakkında net bilgilere ulaşıldığı görülmektedir. Elde edilen sonuca göre, 476 makalenin veri toplama araç türünün klasik yöntemle olduğu bulunmuştur. Bu sayı toplam oranın \% 97.1'ini oluşturmaktadır. Araştırmada, online veri toplama 13 makalede ve karma yöntemin 1 makalede gerçekleştiği görülmektedir.

Tablo 11

TED Ĕ̆itim ve Bilim Dergisinde Yayınlanan Makalelerde Kullanılan Örneklem Düzeyi Dă̆ı̆lımı

\begin{tabular}{lcc}
\hline Örneklem Düzeyi & $\begin{array}{c}\text { Frekans } \\
(\mathrm{f})\end{array}$ & $\begin{array}{c}\text { Yüzdelik } \\
(\%)\end{array}$ \\
\hline Okul Öncesi & 11 & 2.4 \\
İlköğretim (1-5) & 31 & 6.8 \\
İlköğretim (6-8) & 62 & 13.6 \\
Ortaöğretim (9-12) & 45 & 9.9 \\
Lisans (Eğitim Fakültesi) & 117 & 25.6 \\
Lisans (Diğer Fakülteler) & 61 & 13.4 \\
Lisansüstü & 2 & .4 \\
Öğretmenler & 79 & 17.3 \\
Öğretim Elemanları & 10 & 2.2 \\
Veliler & 11 & 2.4 \\
Yöneticiler & 16 & 3.5 \\
Diğgr & 11 & 2.4 \\
Toplam & 456 & 100 \\
\hline
\end{tabular}




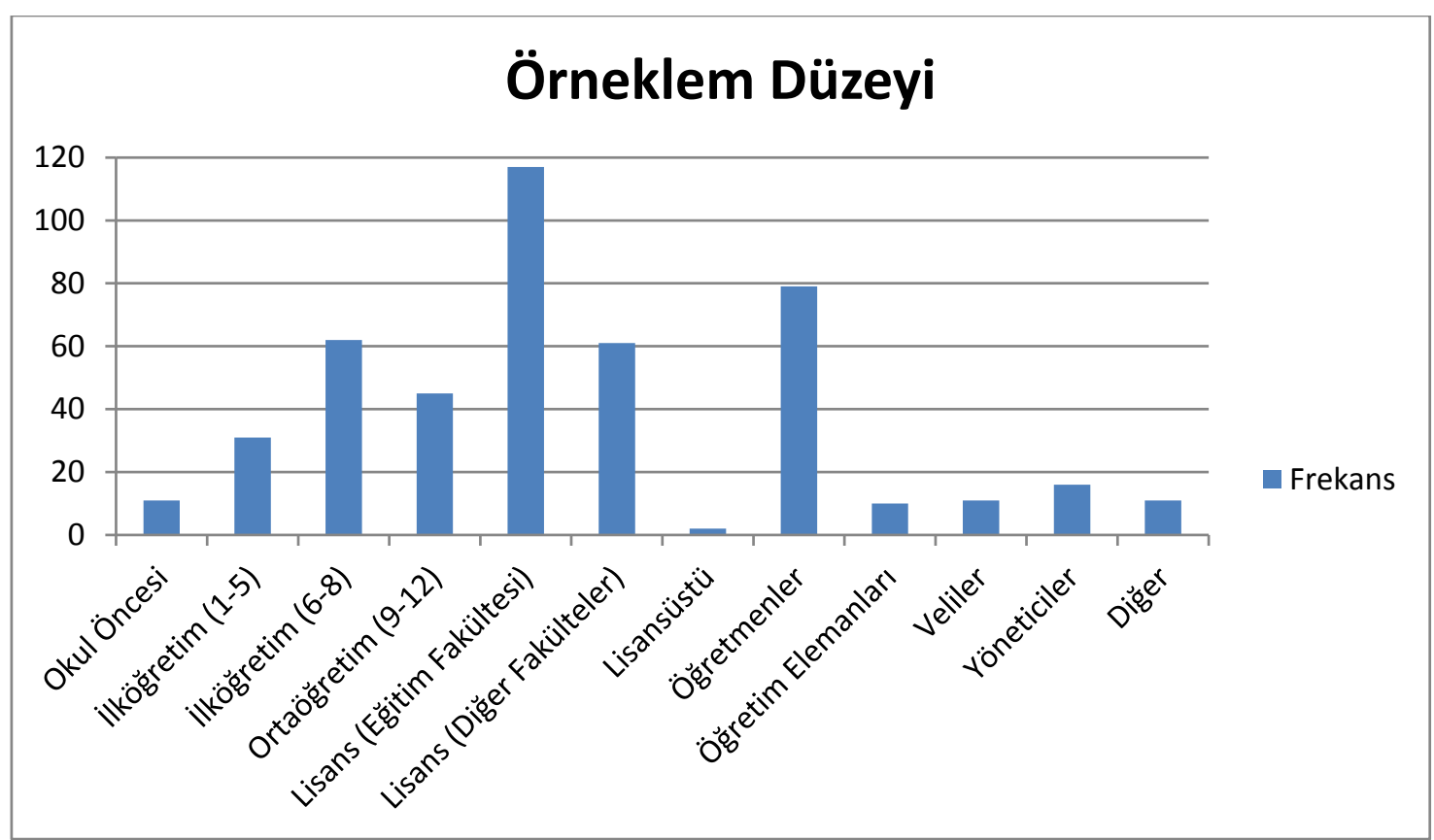

Şekil 9. TED Ĕ̆itim ve Bilim Dergisinde Yayınlanan Makalelerde Kullanılan Örneklem Düzeyi Dağılımı

Yukarıdaki tabloda, TED Eğitim ve Bilim dergisinde yayınlanan makalelerin örneklem düzeyi dağılımı ile ilgili bulgulara yer verilmiştir. Bulgular incelendiğinde, en fazla lisans düzeyinden örneklem alınan çalışmalar yapıldığı görülmektedir. Tablo incelendiğinde, toplamda lisans düzeyinden (Eğitim Fakültesi ve Diğer fakülteler) örneklem alanın çalışma sayısı 178 olduğu görülmektedir. Araştırmada, ikinci olarak öğretmenlerden (79) örneklem gruplarının oluşturulduğu bulunmuştur. Araştırma sonuçları incelendiğinde, lisansüstü düzeyinin (2), öğretim elemanlarının (11), okul öncesi düzeyinin (11), velilerin (11) örneklem olarak kullanıldığ araştırmaların az olduğu önemli bulgulardandır.

Tablo 12

TED Ĕ̆itim ve Bilim Dergisinde Yayınlanan Makalelerde Kullanılan Örneklem Sayısı Dağılımı

\begin{tabular}{lcc}
\hline Örneklem Sayısı & $\begin{array}{c}\text { Frekans } \\
(\mathrm{f})\end{array}$ & $\begin{array}{c}\text { Yüzdelik } \\
(\%)\end{array}$ \\
\hline Okul Öncesi & 58 & 11.8 \\
$11-30$ & 59 & 12 \\
$31-100$ & 102 & 20.8 \\
$101-300$ & 101 & 20.6 \\
$301-1000$ & 118 & 24.1 \\
1000 'den fazla & 52 & 10.6 \\
Toplam & 490 & 100 \\
\hline
\end{tabular}




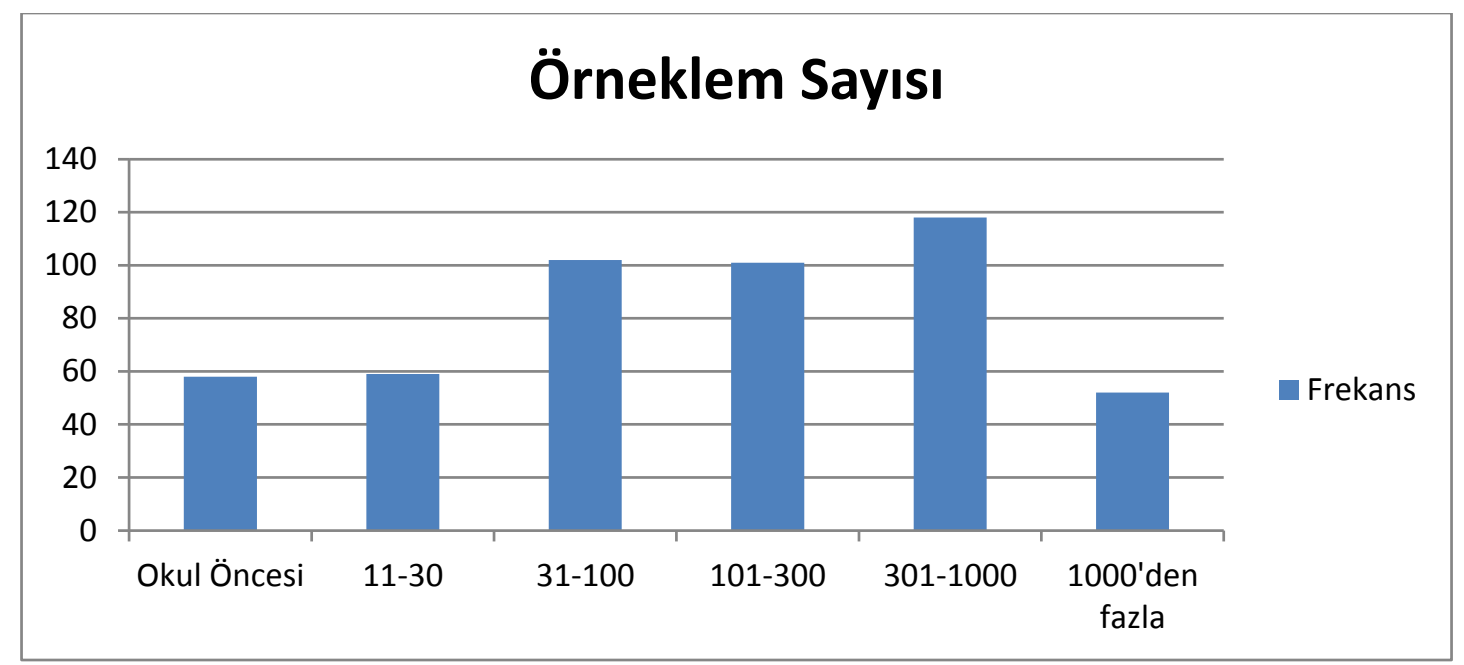

Şekil 10. TED Ĕ̆itim ve Bilim Dergisinde Yayınlanan Makalelerde Kullanılan Örneklem Sayısı Dağılımı

Tablo 12'ye bakıldığında, TED Eğitim ve Bilimde yayınlanan makalelerin örneklem sayısı hakkında betimsel bulgular yer almaktadır. Bulgular incelendiğinde en fazla 301-1000 aralı̆̆ındaki örneklem sayılarıyla (118) çalışıldığı görülmektedir. Bu aralıktan sonra en fazla 31-100 aralığı (102) ve 101-300 aralığının (101) kullanıldığı bulunmuştur. Araştırma sonucuna göre, 1000'den fazla örneklem sayısını oluşturan araştırmaların diğerlerine göre daha az (52) olduğu bulunmuştur.

Tablo 13.

TED Eğitim ve Bilim Dergisinde Yayınlanan Makalelerde Kullanılan Örneklem Seçim Şekli Dağılımı

\begin{tabular}{lcc}
\hline Örneklem Seçim Şekli & $\begin{array}{c}\text { Frekans } \\
(\mathrm{f})\end{array}$ & $\begin{array}{c}\text { Yüzdelik } \\
(\%)\end{array}$ \\
\hline Rastgele & 192 & 39.2 \\
Kolay Ulaşılabilir & 103 & 21 \\
Amaca Uygun & 176 & 35.9 \\
Evrenin Tamamı & 15 & 3,1 \\
Diğer & 4 & .8 \\
Toplam & 490 & 100 \\
\hline
\end{tabular}

\section{Örneklem Seçim Şekli}

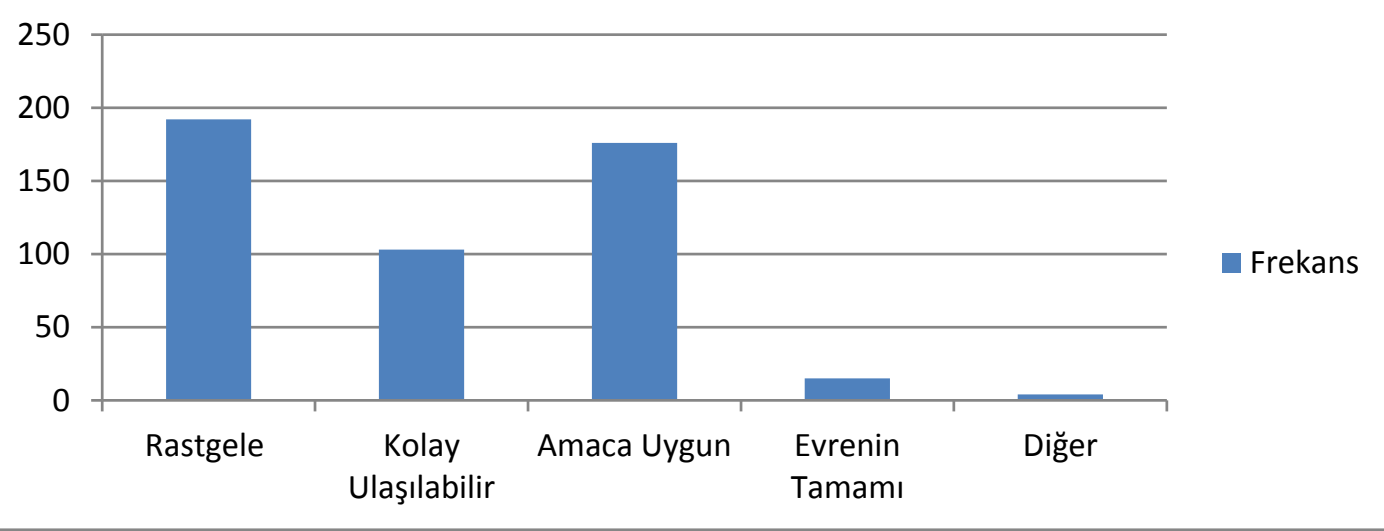

Şekil 11. TED Eğitim ve Bilim Dergisinde Yayınlanan Makalelerde Kullanılan Örneklem Seçim Şekli Dă̆ılımı

Tabloya bakıldı̆̆ında, TED Eğitim ve Bilimde yayınlanan makalelerin örneklem seçim şekli hakkında betimsel bulgular yer almaktadır. Araştırma bulguları incelendiğinde, en fazla rastgele (176) örneklem seçiminin yapıldığg görülmektedir. Bu örneklem seçiminden sonra en fazla, amaca uygun 
örneklem seçiminin (176) yapıldığı bulunmuştur. Araştırmada, diğer örneklem seçiminin (4) ve evreninin tamamının (15) alındığı örneklemlerin daha az tercih edildiği bulunmuştur.

Tablo 14.

TED Eğitim ve Bilim Dergisinde Yayınlanan Makalelerde Kullanılan Veri Analiz Dağılımı

\begin{tabular}{lcc}
\hline Veri Analiz Yöntemi & $\begin{array}{c}\text { Frekans } \\
(\mathrm{f})\end{array}$ & $\begin{array}{c}\text { Yüzdelik } \\
(\%)\end{array}$ \\
\hline Nicel Betimsel & 283 & 55.6 \\
Nicel Kestirimsel & 169 & 33.2 \\
Nitel & 57 & 11.2 \\
Toplam & 509 & 100 \\
\hline
\end{tabular}

\section{Veri Analiz Yöntemi}

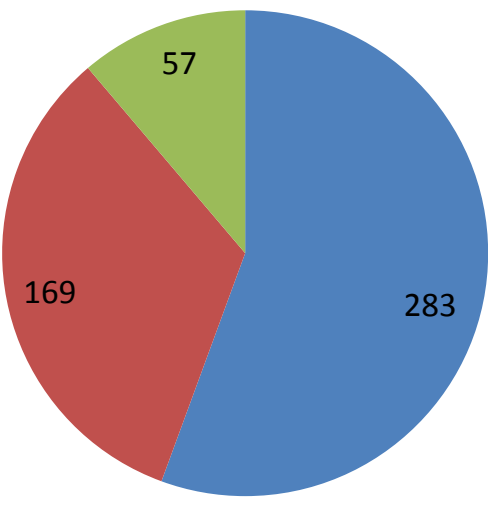

Nicel Betimsel

nicel Kestirimsel

Nitel

Şekil 12. TED Ĕ̆itim ve Bilim Dergisinde Yayınlanan Makalelerde Kullanılan Veri Analiz Dağılımı

Yukarıdaki tabloya bakıldığında, TED Eğitim ve Bilimde yayınlanan makalelerin veri analizi hakkında betimsel bulgular yer almaktadır. Araştırma bulguları incelendiğinde, en fazla nicel betimsel analiz (283) yönteminin seçildiği bulunmuştur. Bu veri analiz yönteminden sonra en fazla, nicel kestirimsel veri analiz (169) yönteminin yapıldığı bulunmuştur. Araştırmada, nitel veri analizlerinin en az tercih edilen (57) analiz yöntemi görülmektedir. 
Tablo 15.

TED Eğitim ve Bilim Dergisinde Yayınlanan Makalelerde Kullanılan Veri Analiz Açıklama Dağılımı

\begin{tabular}{clcc}
\hline \multicolumn{2}{l}{ Veri Analiz Yöntemi Açılama } & $\begin{array}{c}\text { Frekans } \\
(\mathrm{f})\end{array}$ & $\begin{array}{c}\text { Yüzdelik } \\
(\%)\end{array}$ \\
\hline \multirow{5}{*}{ Nicel Betimsel } & Frekans/Yüzde/Çizelge & 88 & 17.3 \\
& Ortalama/Standart & 53 & 10.4 \\
& Sapma & & \\
& Grafikle Gösterim & 12 & 2.4 \\
& Diğer & 4 & .8 \\
\hline & Korelasyon & 44 & 8.6 \\
& t-testi & 70 & 13.8 \\
& Anova & 83 & 16.3 \\
& Manova & 11 & 2.2 \\
Nicel Kestirimsel & Faktör Analizi & 20 & 3.9 \\
& Regresyon & 33 & 6.5 \\
& Non-Parametrik Test & 16 & 3.1 \\
& Yapisal Eşitlik & 49 & 9.6 \\
& Diğer & 22 & 4.3 \\
\hline Içerik Analizi & 54 & 10.6 \\
& Betimsel Analiz & 63 & 12.4 \\
& Diğer & 18 & 3.5 \\
\hline Toplam & & 509 & 100 \\
\hline
\end{tabular}

Yukarıdaki tablo incelendiğinde, , TED Eğitim ve Bilimde yayınlanan makalelerin veri analizi hakkında betimsel bulgular yer almaktadır. Araştırma bulguları incelendiğinde, en fazla nicel betimsel analiz yöntemlerinden yüzde/frekans/çizelge (88) yönteminin seçildiği bulunmuştur. Bu veri analiz yönteminden sonra en fazla, nicel kestirimsel veri analiz yöntemlerinden Anavo (83) yönteminin tercih edildiği bulunmuştur. Bu analiz yöntemlerinden sonra, nicel kestirimsel analiz yöntemlerinden t-testi (70) yönteminin ve nitel analiz yöntemlerinden betimsel analiz (63) yöntemlerinin en fazla tercih edilen yöntemler olduğu bulunmuştur. Araştırmada, nicel betimsel veri analiz yöntemlerinden grafik gösterimi (12); nicel kestirimsel veri analiz yöntemlerinden Manova testinin (11) ve non-parametrik testlerinin en az kullanılan analiz yöntemleri olduğu tespit edilmiştir.

Tablo 16

TED Ĕ̆gitim ve Bilim Dergisinde Yayınlanan Makalelerdeki Öneri Dağılımı

\begin{tabular}{lcc}
\hline Öneriler & $\begin{array}{c}\text { Frekans } \\
\text { (f) }\end{array}$ & $\begin{array}{c}\text { Yüzdelik } \\
(\%)\end{array}$ \\
\hline Bir Boyutlu & 63 & 13.5 \\
İki Boyutlu & 367 & 78.6 \\
Üç ve Daha Fazla Boyut & 37 & 7.9 \\
Toplam & 467 & 100 \\
\hline
\end{tabular}




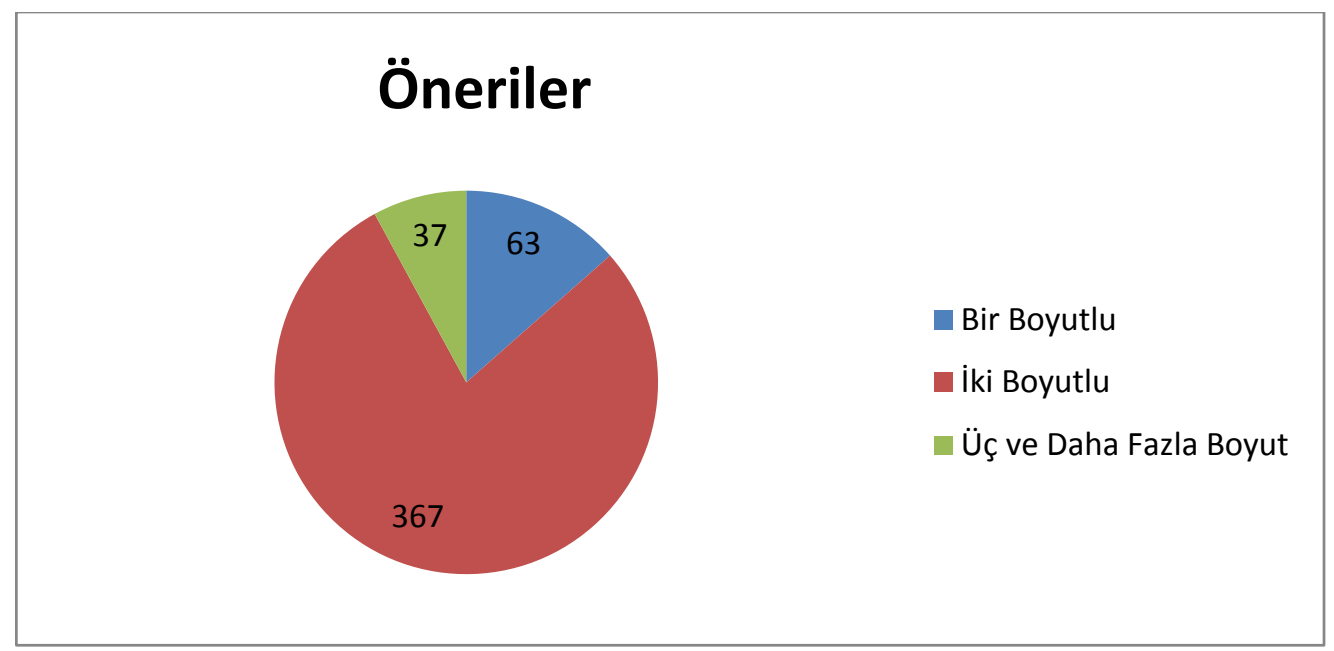

Şekil 13. TED Eğitim ve Bilim Dergisinde Yayınlanan Makalelerdeki Öneri Dă̆̆lımı

Tablo 16 incelendiğinde, TED Eğitim ve Bilimde yayınlanan makalelerin önerileri hakkında betimsel bulgular yer aldığı görülmektedir. Bulgular incelendiğinde, araştırma sonuçlarına ilişkin olarak, iki boyuta yönelik önerilerin en fazla yapılan öneriler olduğu bulunmuştur. İki boyutlu öneriler 367 araştırma bulgusunda yapılmıştır. Araştırma sonuçlarına ilişkin olarak, 63 araştırmada bir boyuta; 37 araştırmada 3 ve daha fazla boyuta ilişkin önerilere ulaşılmıştır.

Tablo 17

TED Ĕ̆itim ve Bilim Dergisinde Yayınlanan Makalelerdeki Tartışma Dağılımı

\begin{tabular}{lcc}
\hline Tartışma & $\begin{array}{c}\text { Frekans } \\
(\mathrm{f})\end{array}$ & $\begin{array}{c}\text { Yüzdelik } \\
(\%)\end{array}$ \\
\hline Bir Boyutlu & 331 & 75.7 \\
İki Boyutlu & 86 & 19.7 \\
Ǘç ve Daha Fazla Boyut & 20 & 4.6 \\
Toplam & 437 & 100 \\
\hline
\end{tabular}

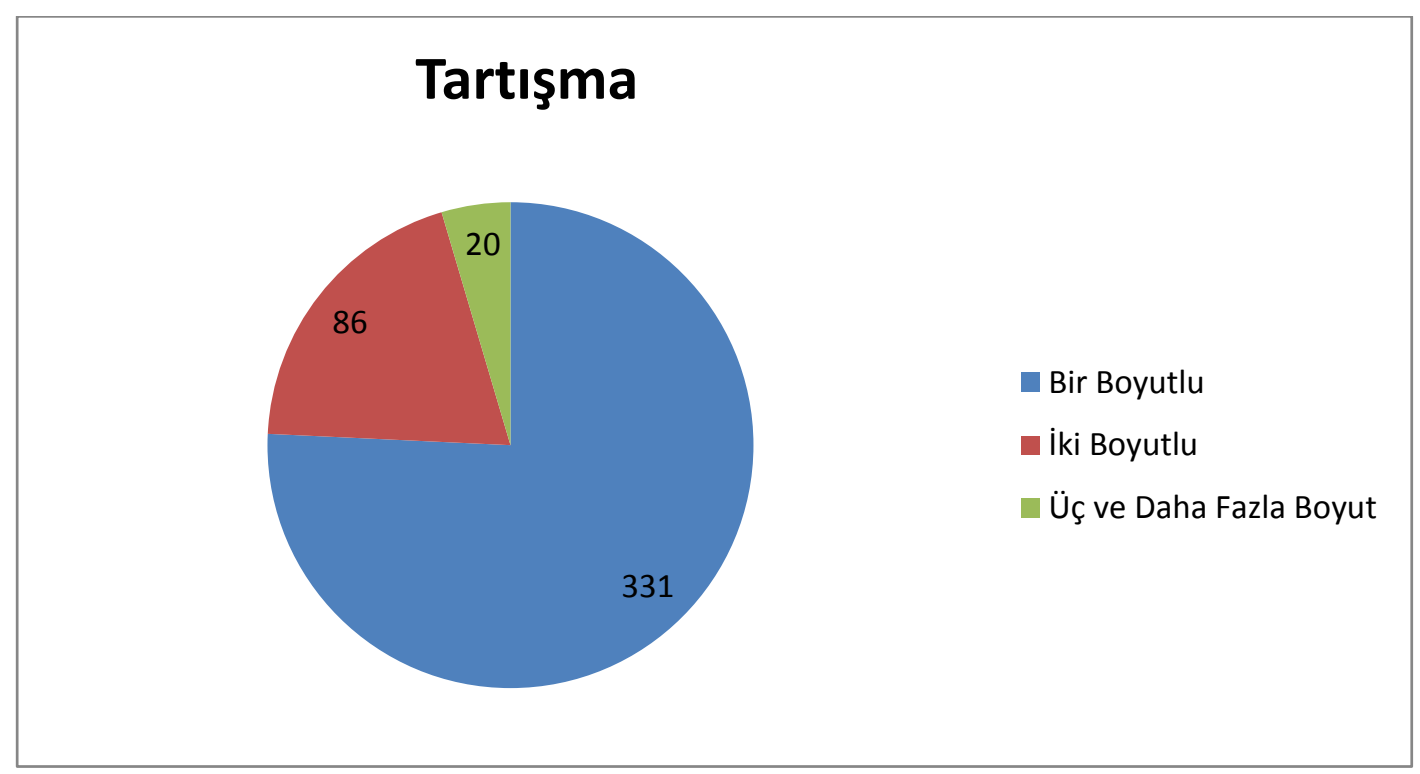

Şekil 14. TED Eğitim ve Bilim Dergisinde Yayınlanan Makalelerdeki Tartışma Dağılımı

Tablo 17 incelendiğinde, TED Eğitim ve Bilimde yayınlanan makalelerin tartışma boyutları hakkında betimsel bulgular yer aldığı görülmektedir. Bulgular incelendiğinde, araştırma sonuçlarına ilişkin olarak, bir boyuta yönelik tartışmaların en fazla yapılan tartışma olduğu görülmüştür. Bir 
boyutlu tartı̧̧ma 331 araştırma bulgusunda yapılmıştır. Araştırma sonuçlarına ilişkin olarak, 86 araştırmada iki boyutlu; 20 araştırmada ise 3 ve daha fazla boyutlu tartışmalara yer verilmiştir.

\section{Tartışma, Sonuç ve Öneriler}

Eğitim ve Bilim dergisinde 2007-2013 yılları arasında 29 sayı içinde yayınlanan 492 makale incelendiğinde bu makalelerin yaklaşı \% 84' ünün bir ya da iki değişkene dayalı olarak desenlenen makaleler olduğu görülmektedir. Eğitim ve Bilim dergisine gönderilen makalelerin büyük bir çoğunluğunun $(\% 36,5)$ Türkiye'nin gelişmiş olarak nitelendirilebilecek olan üniversitelerinde (Hacettepe, Ankara, ODTÜ ve Gazi) görev yapan bilim insanlarına ait olduğu görülmektedir. Tüm makaleler ve yayın yapan bilim insanları incelendiğinde yerli ve yabancı pek çok üniversite kurum ve kuruluştan makalelere rastlanmaktadır. Ancak Milli Eğitim Bakanlığında görev yapan eğitim uzmanı, öğretmen ya da yöneticilere ait çalışmaların sayısının çok az olduğu, Kalkınma Bakanlığı, Planlama Teşkilatı ya da eğitim planlaması ve ekonomisi gibi alanlarda karar alıcıların çalışmalarına rastlanmamıştır. Yine eğitim ile ilgilenen sivil toplum kuruluşları ve onların hazırladığı çalışma ve raporlara rastlanmamıştır. İncelenen makalelerde ortalama referans sıklılığı 37 çalışmadır. İncelenen makalelerin yayın dilinin \% 65 oranında Türkçe, \% 35 oranında ise İngilizce yayınlandı̆̆ 1 görülmektedir. İncelenen makalelerdeki yayın dilinin özellikle son birkaç yılda yoğun bir şekilde İngilizce olarak yayınlandığı görülmüştür.

Yapılan içerik analizinde, dergide yayınlanan makale konuları üç kategori altında toplanmıştır. Birincisi ve en çok yayının görüldügü eğitim bilimleri temel alanında tüm yayınların yaklaşık \% 54' ünün toplandığı ve bu alanda da en fazla yayının eğitim programları ve öğretim ile eğitim yönetimi alt bilim dallarında olduğu görülmektedir. Diğer bir kategori de alan eğitimidir. $\mathrm{Bu}$ alanda da toplam yayınların yaklaşık \% 42' sinin toplandığı görülmektedir. Bu kategori altında ise en fazla yayının Matematik eğitimi ( \%11,2) ve okul öncesi eğitimi $(\%$ 6,7) ile ilgili yayınlar olduğu dikkat çekmektedir. Üçüncü kategori ise eğitim bilimleri dışındaki çalışmalara ait kategoridir. Bu alanda yayınlanan çalışmaların tüm çalışmalar içinde yaklaşık \% 3' ü kadar yer aldığı görülmektedir. Bu alanda ise ön plana çıkan yayınların daha çok sağlık sektörü ve çalışanları ile ilgili olduğu görülmektedir. Karadağ (2009) eğitim bilimlerinde yapılan doktora tezlerini incelediği çalışmasında en fazla çalışmanın eğitim yönetimi ve eğitim programları ve öğretim alanlarında yapıldığını tespit etmiştir. Benzer şekilde Gökçek ve diğ, (2013) 2003-2012 yılları arasında Türkiye' de karma yöntemin kullanılarak yapıldığı çalışmaları incelediği çalışmalarında eğitim bilimleri ile ilgili yapılan çalışmalarda en fazla eğitim yönetimi çalışmalarına yer verildiğine dikkat çekmiştir.

Eğitim ve Bilim dergisinde incelenen çalışmalarda kullanılan yöntemlerin içerik analizi yapıldığında büyük bir çoğunluğun $(\%$ 69,5) nicel araştırma yöntemleriyle yapıldığı̆, nitel çalışmaların oranının \% 22 olduğu karma yöntem ve alanyazın derleme çalışmalarının toplamda ancak \% 6 oranında olduğu görülmektedir. Makalelerde kullanılan yöntemler açıklandığında; nicel araştırmalarda en fazla betimsel ve tarama modellerinin kullanıldığı, tam deneysel ve korelasyonel çalışmaların ise bu yöntemlerden sonra en çok kullanılan yöntemlerden olduğu söylenebilir. Nitel araştırma yöntemleri incelendiğinde ise en fazla olgu bilim deseninde çalışmaların yayınlandığı, bu çalışmalardan sonra ise en fazla örnek olaya dayalı çalışmaların yayınlandı̆̆ı görülmektedir. Karma desenle yayınlanan çalışmaların sayısının oldukça az olduğu söylenebilir. İncelenen çalışmalar içinde meta analizi çalışmalarının yer almadığı görülmüştür. Elde edilen bu bulguların, Gökçek ve diğ, (2013), Sert ve diğ, (2012), Çiltaş (2012), Göktaş ve diğ , (2012), Şimşek ve diğ, (2009) ve Arık ve Türkmen (2009) in çalışmalarıyla benzer olduğu söylenebilir. Yapılan bu çalışmada ve alanyazında bu denli nicel araştırmanın çok olması hızlı, kolay ve daha rahat örnekleme ulaşabilme, daha kolay ve daha kısa sürede verileri toplama ve yorumlayabilme durumları ile açıklanabilir. Ayrıca nitel araştırmaların azlığı konusunda ise Saban ve diğ, (2010) nitel araştırmalar konusunda yaptıkları çalışmada vurguladıkları noktalarla benzeşmektedir. Saban ve diğ, (2010) nitel araştırmaların nicel araştırmalara göre az olmasını nitel araştırma metedolojisinin Türk eğitim bilimleri alanında çalışan akademisyenlerce daha az tercih edildiğine yapılan çalışmalarda da daha çok örnek olay çalışmaları ve olgu bilim deseninde olduğuna vurgu yapmaktadır. 
Yapılan içerik analizinde makalelerde kullanılan veri toplama araçlarının türleri incelendiğinde; en fazla tutum, algı, kişilik test ve ölçeklerinin kullanıldığı, bu araçlardan sonra ise en fazla anket ve görüşme sorularına dayalı geliştirilen veri toplama araçlarının geldiği görülmektedir. Yukarıda sayılan ve en fazla kullanılan araçların yapıları incelendiğinde ise daha çok likert ve çoktan seçmeli test maddelerinden yararlanıldığı görülmektedir. Yapılan içerik analizinde en az gözlenen veri toplama araç türlerinin ise alternatif değerlendirme araçları ve ulusal/uluslararası veri tabanı kayıtlarına dayalı olarak geliştirilen veri toplama araçlarının olduğu görülmektedir. Yağmur Şahin, Kana ve Varışoğlu (2013) yaptığı çalışmasında Türkçe eğitimi ile ilgili olarak yapılan yüksek lisans ve doktora tezlerini incelemiş ve yapılan bu çalışmalarda en fazla tutum ve algı ölçeklerinin kullanıldığını tespit etmiştir. Doğru ve diğ, (2012) tarafından yapılan fen bilimleri eğitiminde yapılan tezlerin incelenmesi isimli çalışmada da benzer bir şekilde daha çok algı ve tutum ölçekleri ile ilgili çalışmaların yapıldığ 1 tespit edilmiştir. Ölçek ve ankete dayalı çalışmaların çok kullanılması kolay ulaşılabilir, maliyetinin düşük, emek ve zaman konusunda diğer çalışmalar göre daha avantajlı olmasından kaynaklandığı söylenebilir (Baş, 2005).

İncelenen makalelerde örneklem seçimi konusunda araştırmacıların daha çok rasgele $(\% 39,2)$ amaca uygun $(\% 35,9)$ ve kolay ulaşılabilir örneklem seçme (\% 21) yöntemlerinden faydalandıkları görülmektedir. Tüm çalışmalar içinde sadece \% 3' ünün evrenin tamamına ulaşıldığı görülmektedir. Yapılan içerik analizinde, örneklem seçiminden sonra örneklem büyüklüğü de incelenmiştir. Çalışmalarda örneklem büyüklüğü ile ilgili olarak en fazla 301-1000 kişilik bir örneklem aralığı (\% 24, 1) ve 31-100 kişilik bir örneklem aralığında $(\% 20,8)$ örneklem grupları ile çalışıldığı görülmektedir. Örneklem büyüklügü ile ilgili olarak 301-1000 kişilik örneklem seçimi ile gerçekleştirilen çalışmaların 49 tanesinin (yaklaşık \% 45) ölçek geliştirme çalışması olduğu dikkat çekmektedir. Yine örnekleme ulaşma noktasında ise 476 çalışmada klasik veri toplama yöntemi kullanılmıştır. Online ve karma yöntemlerin sayısının oldukça az olduğu görülmektedir. Örneklem seçimi ile ilgili olarak dikkat çeken önemli bir nokta ise örneklem gruplarında en fazla lisans öğrencileri ile ilgili çalışmaların olduğudur. Örneklem alınarak yapılan 456 çalışma içinde 117 çalışmanın lisans düzeyindeki öğrenciler ile yapıldığı görülmektedir. Dikkat çeken başka bir bulgu ise 56 çalışmanın yayınlandığı eğitim yönetimi alanında sadece 16 çalışmada yöneticilerden veri toplandığ 1 görülmektedir. Daha çok öğretmen adayları ve öğretmenlerden elde edilen verilerle çalışmaların yorumlanmaya çalışıldığı görülmektedir. Örneklem seçiminde elde edilen verilerle ilgili olarak örneklemin büyüklügü alt kategorisinde elde edilen veriler Göktaş ve diğ, (2012) ve Çiltaş, Güler ve Sözbilir (2012) in çalışmaları ile benzer sonuçlar ortaya koymamıştır. Elde edilen veriler ışığında 301-1000 kişilik bir örneklem büyüklügü bu çalışmada daha fazla tekrar etmiştir. Bu durumun büyük ölçüde belirleyicisi de yaklaşık 49 çalışmada 301 kişiden fazla örneklem alınarak ölçek geliştirme ve uyarlama çalışmalarının yayınlanmasıdır. Ancak her iki çalışmada elde edilen örneklem gruplarıyla ilgili olarak veliler, yöneticiler ve öğretim elemanları ile ilgili yapılan çalışmaların azlığı bir benzerlik göstermektedir. Bu durum, daha büyük bir grup olma ve verilere ulaşma konusunda; öğrenciler ve öğretmenlerle yapılan çalışmaların daha rahat ve kolay yürüdüğü şeklinde yorumlanabilir.

Yapılan içerik analizinde, yayınlanan çalışmalarda kullanılan veri analiz yöntemleri de değerlendirilmiştir. Kullanılan veri analiz yöntemleri noktasında en fazla nicel veri analizlerinin yapıldığı (\% 89) ve bu analizlerden yaklaşık \% 55,6' sının nicel betimsel, \% 33, 2' sinin ise nicel kestirimsel analizler olduğu görülmektedir. Nitel veri anlizleri ise toplam \% 11,2 oranındadır. Veri analiz yöntemlerinden en fazla kullanılanları ise frekans, tablo ve çizelge ile gösterim, anova ve t-testi olarak sıralanmaktadır. Nitel veri analiz yöntemlerinde ise en fazla betimsel analiz yapıldığı görülmektedir. İncelenen 492 makale içinde karma yöntem ya da aynı çalışma içinde hem nitel hem nicel veri analizlerinin de yapıldığı görülmektedir. Yağmur Şahin, Kana ve Varışoğlu (2013), çalışmalarında içerik analizi yaparak lisansüstü tezleri ile eğitim bilimleri alanında yapılan çalışmaları incelemişlerdir. İncelenen çalışmalarda daha çok betimsel analiz yapıldığı, betimsel analizde kullanılan tekniklerin ise frekans, yüzde ve çizelge ile gösterimlerin olduğu yönündedir. Nicel kestirimsel çalışmalarda ise daha çok, korelasyon, t-teti ve anova gibi analizlerin yapıldığı görülmektedir. Ayrıca Bektaş, Dündar ve Ceylan (2013), Doğru ve diğ, (2010), Göktaş ve diğ, (2012) 
nin bulguları da elde edilen bu verileri destekler niteliktedir. Bu açıdan değerlendirildiğinde yapılan bu çalışma ile anılan çalışmalar arasında bir benzerlik olduğu söylenebilir. Ve daha çok bu analizlerin yapılma nedenleri ise değişkenler arasında incelenen özelliklerin daha az ve kolay açılanabilir şekilde kurgulanması, daha kolay yorumlanabilmesi olarak gösterilebilir.

İçerik analizi yapılan araştırmalarla ilgili olarak tartışmaların boyutları; paydaşlara yönelik, sinırlılıkları içerme durumu, yöntem vb. şeklinde bir sinıflama ile analiz edilmiştir. İncelenen çalışmalarda makalelerle ilgili tartışmaların \% 75,7 oranında tek boyutlu olarak tartışıldığı görülmüş̧ür. Bu oran analiz edildiğinde çoğu çalışmada sadece literatür desteği ile tartışmanın yapıldığı sınırlılık ve paydaşları da içeren bir tartışma yapılmadığı görülmüştür. Yine yapılan içerik analizinde çalışma sonunda getirilen öneriler; paydaşlar, araştırmacılar, politika üreticileri ve karar alıcılar ve diğer şeklinde gruplandırılarak analiz edilmeye çalışılmıştır. Öneriler incelendiğinde ise \% 78,6 oranı ile iki boyutlu şekilde bir öneriler sunulduğu görülmektedir.

İçerik analizi sonucunda elde edilen verilere dayalı olarak, daha çok eğitim bilimleri alanında program geliştirme ve eğitim yönetimi alanlarında daha fazla yayın yapıldığı görülmektedir. Alan eğitiminde ise matematik eğitimi alanında yayınların yoğunlaştığı görülmektedir. Buna göre, eğitim bilimlerinin ve alan eğitimlerinin farklı alanlarında akademik yayınlarının yapılması TED Eğitim ve Bilimleri Dergisin eğitim alanlarını kapsayıcı olma özelliğine önemli katkılar sağlayabilir.

Araştırma sonucunda, dergide yayınlana makalelerin, nicel yöntemlerle yapıldı ̆̆ı görülmektedir. Aynı zamanda, nicel yöntemler içinde deneysel olmayan ve betimsel araştırmaların çok olduğu görülmüştür. Bu bağlamda düşünüldüğünde, bundan sonra yayınlanacak makalelerin nitelikli olması şartıyla nitel, karma yöntemler, deneysel yöntemler ile desenlenmiş olması dergiyi araştırma yöntemleri konusunda da zenginleştirecektir.

Araştırma sonucunda, yayınlanan makalelerde kullanılan örneklem seçiminin daha çok kolay ulaşılabilir ve rastgele örneklemler olduğu ve daha çok lisans öğrencilerden örneklem seçildiği tespit edilmiştir. Buna göre, yapılacak çalışmalarda, çalışma desenine uygun örneklem seçimi, eğitimle ilgili tüm paydaşların örneklem grubu olarak seçilmesi; yayınların niteliğine, uygulama alanlarına, politika geliştiricilerine, alanyazına ve sonraki çalışmalara önemli veri kaynağı oluşturabilir.

Araştırma sonucunda, yayınlanan makalelerde kullanılan veri analiz yöntemlerinin daha çok betimsel analiz, fark ve ilişkisel analizler olduğu bulunmuştur. Bu doğrultuda düşünüldüğünde, çok değişkenli çalışmaların, analizler ve farklı analiz modellerinin kullanılması derginin gelişimine önemli katkılar sağlayabilir. Özellikle gelişen analiz yöntemleri ve derinlik kazanan içeriklere oranla örneklem sayılarının büyütülmesi önemsenmektedir. Hipotez sayısını amaca uygun olacak şekilde artırıldığı, yöntem ve uygulamaların zenginleştirildiği, eğitimle ilgili araştırmacılara ve karar alıcılara yönelim sağlayacak kapsamdaki çalışmalar teşvik edilmelidir.

Bununla birlikte, öğrenciler, aileleri ve okul sosyal çevresi, eğitim yatırım ilişkisi, alt yapı iyileştirmeleri, eğitim çıktılarının değerlendirilmesi, uluslararası rekabet ve gelişmeler, amaca uygun seçilmiş örneklemle çalışmak, nitel veya karma model kullanımı, zengin ve veri sağlamaya daha etkin yöntemlerle tasarlanmış nitelikli makaleler, değişken sayısı ve tartışma boyutlarının zenginleştirilmesi, yöntemsel hataların azaltılması, multi-disipliner çalışmaları yayına daha fazla almak için öncelik oluşturularak politikalar geliştirilebilir. 


\section{Kaynakça}

Arık, R. S. \& Türkmen, M. (2009). Eğitim bilimleri alanında yayımlanan bilimsel dergilerde yer alan makalelerin incelenmesi. Retrieved December 2009, http://oc.eab.org.tr/egtconf/pdfkitap/pdf/488.pdf.

Baş, T. (2005). Anket nasıl hazırlanır, uygulanır, değerlendirilir. Ankara: Seçkin Yayıncılık.

Bektaş, M., Dündar, H., Ceylan, A.(2013). Ulusal sınıf öğretmenliği eğitimi sempozyumu (USOS) bildirilerinin çeşitli değişkenler açısından incelenmesi. Uşak Üniversitesi Sosyal Bilimler Dergisi. 6(2):201-226.

Chang, Y.H.,Chang, C.Y., \& Tseng, Y.H (2010). Trends of science education research: an automatic content analysis. Journal of Science Educational Technology, (2010) 19:315-331DOI 10.1007/s10956009-9202-2.

Cohen, L., Manion, L. \& Morrison, K., (2007). Research methods in education. RoutledgeFalmer, London.

Çalık, M., Ünal, S., Coştu, B. \& Karataş, F. O. (2008). Trends in Turkish science education. Essay in education. Special Edition, 23-46.

Çiltaş, A. (2012). 2005-2010 yılları arasında matematik eğitimi alanında Türkiye'de yapılan yüksek lisans ve doktora tez çalışmalarının içerik analizi, The Journal of Academic Social Science Studies, $5(7), 211-228$.

Çiltaş, A., Güler, G. \& Sözbilir, M. (2012).Türkiye'de matematik eğitimi araştırmaları: bir içerik analizi çalışması. Kuram ve Uygulamada Eğitim Bilimleri, 12(1),565-580.

Doğru, M., Gençosman, T., Ataalkın, A.N. \& Şeker, F. (2012).Fen bilimleri eğitiminde çalışılan yüksek lisans ve doktora tezlerinin analizi. Türk Fen Eğitimi Dergisi, 9(1), 49-64.

Falkingham, L. T. \& Reeves, R. (1998). Context analysis a technique for analysing research in a field, applied to literature on the management of $\mathrm{R}$ and $\mathrm{D}$ at the section level. Scientometrics, 42(2), 97120.

Gökçek, T., Babacan, F.Z., Kangal, E., Çakır, N. \& Kül, Y. (2013). 2003-2012 yılları arasında türkiye'de karma araştırma yöntemiyle yapılan eğitim çalışmalarının analizi. International Journal of Social Science, Doi number: http://dx.doi.org/10.9761/JASSS1655. 6( 7): 435-456.

Göktaş, Y., Küçük, S., Aydemir, M., Telli, E., Arpacık, Ö., Yıldırım, G., \& Reisoğlu, İ. (2012).

Educational technology research trends in turkey: a content analysis of the 2000-2009 decade. Educational Sciences: Theory \& Practice, 12(1), 191-196.

Gülbahar, Y. \& Alper, A. (2009). Trends and issues in educational technologies: A review of recent research in TOJET. TheTurkish Online Journal of Educational Technology - TOJET, 8(2), Article 12.

Kablan, Z.,Topan, B. ve Erkan, B. (2013). Sınıf içi öğretimde materyal kullanımının etkililikdüzeyi: Bir meta-analiz çalışması. Kuram ve Uygulamada Eğitim Bilimleri, 13 (3), 1629-1644.

Kaptan, S. (1998). Bilimsel araştırma ve istatistik teknikleri (11.Baskı). Ankara: Tek Işık Web Ofset.

Karadağ, E. (2009). Eğitim bilimleri alanında yapılmış doktora tezlerinin incelenmesi. Ahi Evran Üniversitesi Ĕ̆itim Fakültesi Dergisi, 10(3), 75-87.

Karadağ, E. (2010). Eğitim bilimleri doktora tezlerinde kullanılan araştırma modelleri: nitelik düzeyleri ve analitik hata tipleri, Kuram ve Uygulamada Ĕ̆itim Yönetimi, 16(1), 49-71.

Kılıç-Çakmak, E.,Çebi, A., Mihçi, P., Günbatar, M.S., Akçayir, M. (2013). A content analysis of educational technology research in 2011. 4th International Conference on New Horizons in Education. INTE 2013 Proceedings Book, 397-409.

Mortimore, P. (2000). Does educational research matter? British Educational Research Journal, 26 (1),5-24.

Saban, A.,Eid-Koçbeker, B.N., Saban, A., Alan, S., Doğru, S., Ege, İ., Arslantaş, S., Çınar, D. \& Tunç, P. (2010). Eğitim bilim alanında nitel araştırma metodolojisi ile gerçekleştirilen makalelerin analiz edilmesi. Selçuk Üniversitesi Ahmet Keleşoğlu Ĕ̆itim Fakültesi Dergisi, (30), 125-142. 
Sert, G., Kurtoğlu, M., Akıncı, A. \& Seferoğlu, S. S. (2012).Öğretmenlerin teknoloji kullanma durumlarını inceleyen araştırmalara bir bakış: bir içerik analizi çalışması. Akademik Bilişim, 1-3 Şubat 2012 / Uşak Üniversitesi, UŞAK.

Sözbilir, M., Kutu, H., \& Yaşar, M. D. (2012). Science education research in Turkey: A content analysis of selected features of papers published. In J. Dillon\& D. Jorde (Eds). The World of Science Education: Handbook of Research in Europe (pp.341-374). Rotterdam: Sense Publishers.

Şimşek, A., Özdamar, N., Uysal, Ö., Kobak, K., Berk, C., Kılıçer, T., \& Çiğdem, H. (2009). İkibinli yıllarda Türkiye'deki eğitim teknolojisi araştırmalarında gözlenen eğilimler. Kuram ve Uygulamada Eğitim Bilimleri Dergisi, 9(2), 115-120.

Tomakin, E., Yeşilyurt, M. (2013) Bilgisayar destekli yabancı dil öğretim çalışmalarının meta-analizi: türkiye örneği, YYÜ Eğitim Fakültesi Dergisi, 10( 1), 248-263,

Yağmur Şahin, E., Kana, F., \& Varışoğlu, B. (2013). Türkçe eğitimi bölümlerinde yapılan lisansüstü tezlerin araştırmaeğilimleri. International Journal of Human Sciences, 10(2), 356-378.

Yalçın, N.,Bilican, S., Kezer, F. \& Yalçın, Ö. (2009). Hacettepe üniversitesi eğitim fakültesi dergisinde yayımlanan makalelerin niteliği: İçerik analizi. Retrieved December 6 2009, http:// oc.eab.org.tr/egtconf/pdfkitap/pdf/488.pdf.

Yıldırım, A.\& Şimşek, H. (2006). Sosyal bilimlerde nitel araştırma yöntemleri, (5. Baskı), Ankara: Seçkin Yayıncilik. 